\title{
A INFLUÊNCIA DO DIREITO PORTUGUÊS NA FORMAÇÃO DO DIREITO BRASILEIRO
}

António Santos Justo

Professor catedrático da Universidade de Coimbra.

Palestra proferida em 26/ago/2008 inaugurando o semestre letivo da FA7.

\section{NOTA PRÉVIA}

Quando, em 22 de Abril de 1500, a armada portuguesa comandada por Pedro Álvares Cabral chegou à Terra de Vera Cruz, o Direito Português penetrou no Brasil, onde, durante vários séculos, teve vigência e, hoje, conserva uma influência particularmente importante que permite afirmar, sem a mínima ousadia, que partilhamos, Portugueses e Brasileiros, do mesmo direito: o direito luso-brasileiro ${ }^{1}$.

Este fenómeno nada tem, alias, de surpreendente se recordarmos a sábia lição dos jurisconsultos da Escola Histórica, para os quais o Direito é componente de uma cultura que distingue e individualiza ${ }^{2}$. No nosso caso, a cultura lusíada construída superiormente por gentes de Portugal e do Brasil, com as aventuras e desventuras que marcam as nossas vidas; e cantada, em versos inapagáveis, pelo imortal Luís de Camões.

Durante muitos anos, Coimbra foi o palco da nossa cultura e aí, na vetusta Universidade do século XIII, conviveram e formaram-se jurisconsultos portugueses e brasileiros que edificaram o edifício jurídico que é nosso e nos distingue. Depois, quando em 1 de Março e 15 de Maio de 1828 foram criados os cursos jurídicos de São Paulo e de Olinda, respectivamente, nos Mosteiros de São Francisco e de São Bento, os estudantes do Sul e do Norte não deixaram de estudar o mesmo direito, preparados com igual formação jurídica por Mestres iluminados pela lucerna iuris que, no século XII atraiu Portugueses a Bolonha e a partir do século XVI serviu de atracção a Brasileiros que até 7 de Setembro de 1822 partilhavam a mesma nacionalidade.

\footnotetext{
${ }^{1}$ Vide A. SANTOS JUSTO, O direito brasileiro: raizes históricas na RBDC 20 (Rio de Janeiro, 2002) 131.

${ }^{2}$ Vide A. CASTANHEIRA NEVES, Escola histórica do direito em Digesta $2^{\circ}$. (Coimbra Editora / Coimbra, 1995) 206; e SANTOS JUSTO, Nótulas de história do pensamento jurídico (história do direito) (Coimbra Editora / Coimbra, 2005) 57-59.
} 
Com a fundação de Portugal por volta do ano 1140, o velho direito do reino de Leão vigente no Condado Portucalense tornou-se português: a História do nosso Direito começou aí, embora os seus antecedentes remontem a um passado por vezes remoto, como o direito dos celtas e iberos, dos invasores romanos, germânicos e muçulmanos e dos povos que lutaram pela reconquista cristã $\tilde{3}^{3}$. A ciência jurídica dos Romanos jazia, há muito, numa situação de esquecimento profundo que só não é total porque nos Conventos, Catedrais e Igrejas se conservou o velho Corpus Iuris Civilis que alimentava a chama que teimosamente não se apagava na expectativa de um dia poder reacender e iluminar a ciência jurídica ${ }^{4}$.

E foi assim que, um século depois de o direito romano ter renascido em Bolonha $^{5}$, aquela iuris scientia penetrou em Portugal para transformar o velho direito empírico, rude e grosseiro, num direito novo, capaz de satisfazer as exigências duma sociedade agitada pelo progresso ${ }^{6}$. Assinala-se, em 1211, nas Cortes de Coimbra, o início do movimento legislativo que libertou a prática jurídica de costumes obsoletos e injustos. $\mathrm{Na}$ Universidade, fundada por volta de 1290, a ciência jurídica afirmava-se e o direito progredia: o debate jurídico, iniciado pelos Glosadores e continuado pelos Comentadores ${ }^{7}$ decorria igualmente em Coimbra, com base nas mesmas fontes. E o Estado ia-se construindo à volta da figura do princeps, cuja voluntas se manifestava na lei, instrumento forte de moralização do direito.

A velha vindicta privata desaparecia paulatinamente no mesmo ritmo em que o Estado se afirmava, espalhando os seus tribunais. E a economia, de base agrícola, florescia com novas leis e contratos que, importados do direito romano, voltavam a ter um ambiente propício para se dinamizarem: referimos, a propósito, a enfiteuse, a complantação, a consignação de rendimentos, o penhor imobiliário e a compra e venda de rendas ${ }^{8}$.

Neste ambiente, marcado pelo progresso que tornava cada vez mais pequeno o solo português, entrámos na época das Ordenações e dos Descobrimentos.

Primeiro, as Ordenações Afonsinas, aprovadas em finais de 1446 ou princípios de 1447, mandadas elaborar por D. João I, o Rei da Boa Memória, e promulgadas, mais tarde, pelo seu neto, D. Afonso V, o Africano. Aí se consagram,

\footnotetext{
${ }^{3}$ Vide Mário Júlio de ALMEIDA COSTA, História do direito português ${ }^{3}, 2^{\mathrm{a}}$. reimpressão (Almedina / Coimbra, 2000) 67-168 e 173-180.

${ }^{4}$ Vide Sebastião CRUZ, Direito romano (ius romanum) I. Introdução. Fontes ${ }^{4}$ (Ed. do Autor / Coimbra, 1984) 91-94.

${ }^{5}$ Sobre a Escola de Bolonha, vide ALMEIDA COSTA, o.c. 210-218; Sebastião CRUZ, o.c. 96-97; e SANTOS JUSTO, Nótulas de história do pensamento jurídico, cit. 26-28.

${ }^{6}$ Vide ALMEIDA COSTA, o.c. 223-236.

${ }^{7}$ Sobre a Escola dos Comentadores, vide ALMEIDA COSTA, o.c. 236-241; Sebastião CRUZ, o.c. 97-99; e SANTOS JUSTO, Nótulas de história do pensamento jurídico, cit.28-31.

${ }^{8}$ Vide ALMEIDA COSTA, o.c. 196-200.
} 
como fontes do direito português, a lei, o costume e o estilo da corte: aquela expressa a vontade do rei; o costume traduz uma prática constante e reiterada acompanhada da conviç̧ão da sua obrigatoriedade jurídica; e o estilo da corte impõe-se como jurisprudência constante dos tribunais superiores ${ }^{9}$. Na sua ausência, abre-se um espaço para o direito subsidiário que integrará as lacunas: direito romano, direito canónico, glosa de Acúrsio, opiniões de Bártolo e vontade do rei ${ }^{10}$. A influência da ciência jurídica leccionada em Coimbra é inequívoca. Estas Ordenações vigoraram cerca de 60 anos e, portanto, o tempo suficiente para ainda vigorarem no Brasil.

Depois, em 1521, D. Manuel I, o Rei Venturoso, promulgou as Ordenações Manuelinas que actualizaram as Afonsinas. Mantêm-se as fontes do direito pátrio e o direito subsidiário é alterado: passa a recorrer-se à opinio communis doctorum para filtrar a glosa de Acúrsio e as opiniões de Bártolo, afastando a sua aplicação, se lhe for contrária ${ }^{11}$. A ciência jurídica portuguesa revela-se actual, acolhendo ideias defendidas na Escola de Bártolo. Foram sobretudo estas Ordenações que os Portugueses introduziram no Brasil, embora não devamos esquecer os direitos locais com que necessariamente conviveram. Durante esses tempos, assistimos a duas inovações profundas do direito português: referimo-nos ao instituto dos assentos e à consagração do regime geral da comunhão de bens como supletivo.

Peço vénia para os abordar.

Os assentos consubstanciam interpretações autênticas das leis, que o rei Venturoso ordenou fossem feitas pelo Tribunal Superior do Reino, a Casa da Suplicação. Perante dúvidas sobre o sentido normativo de um preceito legislativo, os tribunais deviam pedir-lhe que fixasse o que devia ser observado no Reino. O Regedor convocaria os Desembargadores e, fixado esse sentido, era registado num livrinho e, daí, o nome de assentos. Assim se garantiria a segurança do comércio jurídico numa época particularmente importante. No entanto, porque as várias Relações (do Porto, de Goa, do Rio de Janeiro e da Baía) começaram, sem autorização régia, a emitir assentos, criou-se o caos com diferentes interpretações, só mais tarde, no século XVIII, afastado pela Lei da Boa Razão ${ }^{12}$.

Quanto ao regime supletivo da comunhão geral dos bens, a sua história merece também referência. Como sabemos, o problema da pertença dos bens levados e adquiridos na constância do matrimónio depende da concepção da família e, por isso, variam de país para país ${ }^{13}$.

9 Vide ALMEIDA COSTA, o.c. 273281 e 304-308.

${ }^{10}$ Vide ALMEIDA COSTA, o.c. $308-317$.

${ }^{11}$ Vide ALMEIDA COSTA, o.c. 281-288 e 314-316.

${ }^{12}$ Vide ALMEIDA COSTA, o.c. 300-304 e 367-369.

${ }^{13}$ Vide SANTOS JUSTO, Relações patrimoniais entre cônjuges: do direito romano aos direitos português e brasileiro em El dereceho de familia. De Roma al derecho actual (Universidad de Huelva, Publicaciones / Huelva, 2004) 323. 
Esta dependência é também visível no direito de Roma. Nos primeiros tempos, dominados pelo entendimento da família como um conjunto de pessoas e bens sujeitos ao poder de um chefe, os bens que a mulher levasse para a nova família eram adquiridos pelo paterfamilias que tanto podia ser o marido como o sogro. Estávamos perante o regime da absorção de bens. Depois, com a afirmação da independência da mulher casada (matrimónio sem a conventio in manum), aquele regime foi substituído pela separação de bens ${ }^{14}$.

Na Idade Média, o Cristianismo foi-se afirmando, impondo-se paulatinamente a ideia de comunhão geral de bens. Entretanto, em Portugal, dominaram, nos primeiros tempos, o regime denominado casamento por arras (ou dote ex marito) e a comunhão de adquiridos. Oriundo do direito visigótico, o casamento por arras traduzia-se numa espécie de separação de bens, embora o marido administrasse os bens (arras) da mulher e pudesse dispor mesmo livremente dos seus bens móveis. Tratando-se de alienação de bens imóveis, exigia-se o consentimento dos dois cônjuges. O regime de comunhão de adquiridos (ou ganâncias, gaanças) aparece consagrado nos costumes de diversas localidades. Um e outro não afastavam, no entanto, a comunhão geral de bens se os nubentes a desejassem ou a lei canónica determinasse ${ }^{15}$.

Todavia, se a comunhão de ganâncias é dominada pela ideia de igualdade (embora ressalvado o papel de direcção e administração do marido) e pela comunhão dos bens adquiridos, estavam criadas as condições para desabrochar o novo sistema da comunhão geral de bens. Já aparece no século XII no foral de Ferreira de Aves e surge consagrada numa lei de D. Afonso III, embora como regime convencional ao lado do supletivo "casamento por arras". As nossas Ordenações falam, a propósito, de Carta de $\mathrm{Metade}^{16} \mathrm{e}$ informam que esta prática obedece ao costume da Estremadura ${ }^{17}$. Também se apresenta como regime supletivo no foral de Sabadelhe e nos costumes de Santarém ${ }^{18}$.

No Reinado de D. Manuel I, este regime é praticado, como supletivo, por força do costume, na Estremadura, no Alentejo e no Algarve, ou seja, no Sul de Portugal, enquanto no Norte revestia carácter convencional. Porém, com o tempo a sua dimensão supletiva alastrou-se ao Norte, impondo-se universalmente como regime regra nas Ordenações Manuelinas, que determinam: "Todos os casamentos que forem feitos em Nossos Reinos e Senhorios, se entendem ser feitos por carta de metade" ". Como explicação, afirma-se que "tenderia a brotar em meios conjugais humildes, onde as fortunas se equilibravam numa apagada mediocridade,

\footnotetext{
${ }^{14}$ Vide SANTOS JUSTO, ibidem 323-331.

${ }^{15}$ Vide SANTOS JUSTO, ibidem 341-345.

${ }^{16} \mathrm{Cf}$. Ordenações Afonsinas IV,12.

${ }^{17} \mathrm{Cf}$. Ordenações Afonsinas, IV,14,4.

${ }^{18}$ Vide SANTOS JUSTO, ibidem 344-345.

${ }^{19} \mathrm{Cf}$. Ordenações Manuelinas IV,7pr.
} 
onde a vida decorria num contacto permanente e num relativo desapego de preocupações egoístas, onde a colaboração efectiva da mulher reclamava uma franca participação". Esta situação económica localizava-se no Sul, enquanto, no Norte, "a grandeza das propriedades servia de base ao predomínio de famílias nobilitadas (que viviam com) mais apego ao regime tradicional do casamento por arras, restringindo a comunhão às gaanças conjugais" ${ }^{20}$.

$\mathrm{Na}$ base desta evolução parece estar a mensagem cristã que começou por ser ouvida no Sul, povoado por gente pobre e oprimida, que nada tinha a perder no mundo dos bens materiais. Mensagem aquela que se adapta ao rigor do "duo in carne" de que fala o Evangelho de S. Marcos (XIX,5) e que, alastrando para todo o nosso País, explica a afirmação da comunhão geral de bens como regime regra, sem afastar a liberdade de os nubentes optarem pela comunhão de adquiridos ou pela separação de bens ${ }^{21}$.

Como veremos, este regime manteve-se, em Portugal, até 1966 e, no Brasil, até à Lei $n^{\circ}$. 6.515, de 26 de Dezembro de 1977.

Em 1580, Portugal perdeu a sua independência e, volvidos 23 anos, no reinado de D. Filipe II, iniciaram a sua vigência as novas Ordenações, ditas Filipinas, mandadas elaborar por Filipe I. Repetem-se as fontes do direito português e do direito subsidiário ${ }^{22}$, que se mantiveram em vigor, em Portugal e no Brasil, até aos Códigos Civis, respectivamente, de 1867 e de 1916. Ou seja, vigoraram, no Brasil, quase 50 anos mais do que em Portugal e passados pouco menos de 100 anos do Grito de Ipiranga.

Durante estes tempos, o pensamento jurídico sofreu uma transformação profunda. Primeiro, com o Humanismo jurídico da Renascença e, depois, com a Segunda Escolástica.

Vindo do século XV, o Humanismo jurídico manteve-se na centúria seguinte. A liberdade de interpretação constituiu uma bandeira de combate à communis opinio doctorum; e o método de ensino histórico-crítico opôs-se ao velho método escolástico. O direito romano foi, pela primeira vez, seriamente abalado, havendo quem defendesse a sua substituição pelo direito natural ou a sua redução às normas e princípios que se mantivessem actuais: é a primeira versão do usus modernus pandectarum que viria a impor-se decisivamente mais tarde, no século XVIII. Mas houve também quem, mantendo-se fiel à necessidade do estudo do direito romano, sustentasse que o direito justinianeu devia ser substituído pelo direito da época clássica. Esta orientação tipicamente renascentista impôs-se na famosa Escola Culta, Humanista ou cujaciana que se desenvolveu em França ${ }^{23}$, contribuindo

${ }^{20}$ Transcrevemos Manuel PAULO MER A, Evolução dos regimes matrimoniais II (Imprensa da Universidade / Coimbra, 1913) 110-113.

${ }^{21}$ Vide SANTOS JUSTO, ibidem 345-347.

22 Vide ALMEIDA COSTA, o.c. 288-293.

${ }^{23}$ Sobre o Humanismo Jurídico e a Renascença, vide Sebastião CRUZ, o.c. 99; ALMEIDA COSTA, o.c. 319-324; e SANTOS JUSTO, Nótulas de história do pensamento jurídico, cit. 37-39 
decisivamente para o florescimento da cultura jurídica francesa a que, em grande parte, é devido o famoso Código de Napoleão de 1804: sem grandes juristas não se fazem códigos, sobretudo da envergadura do Code Civil. Também em Portugal o Humanismo jurídico se fez sentir, embora a sua história continue por fazer.

Particularmente importante foi, no entanto, a Segunda Escolástica que teve por palco a Península Ibérica e, por isso, também é conhecida por Escola Peninsular do Direito Natural. Decorreu nos séculos XVI e XVII num ambiente em que os espíritos mais representativos da cultura se dividiam em duas classes: a que, embora herdeira do humanismo, procurava reatar a sua mais íntima ligação com a Idade Média, olhando como que para trás; e a que procurava tirar do Humanismo as últimas consequências, olhando como que para a frente ${ }^{24}$.

Foi a primeira linha que predominou em Espanha e Portugal, onde se destacaram juristas de grande envergadura que constituem a glória do pensamento jurídico ibérico. Salientamos Francisco de Vitória, a quem alguns autores atribuem a paternidade do direito internacional público; Francisco de Molina, atento aos problemas económicos; Serafim de Freitas, que defendeu a doutrina do mare clausum contra Hugo Grócio; e sobretudo Francisco Suarez, defensor da doutrina política da soberania popular inicial e alienável, que viria, pouco tempo depois, a ser invocada para justificar a Restauração da Independência de Portugal, em 1640 25 .

Fora da Ibéria, impôs-se uma nova corrente do pensamento jurídico: falamos da Escola Racionalista do Direito Natural que, nos séculos XVI e XVII desenvolveu a sua actividade na Holanda, na Inglaterra e na Alemanha. O entendimento do direito transformou-se radicalmente: a fonte do direito natural deixa de ser Deus, para ser a razão dos homens. Estamos perante uma orientação laica que vê no homem não uma obra divina, mas um ser natural; por isso, liberta-se da Teologia e defende a autonomia científica do direito natural como ciência dos princípios supremos da convivência social. Como fonte do direito, a razão humana constrói normas que derivam logicamente de outras e têm, nas tendências psicológicas da natureza empírica do homem, a sua base e ponto de partida: a sociabilidade, a felicidade, o egoísmo ou a bondade. Depois, a razão recolhe essas normas em sistemas que se consideram perfeitos, completos, acabados e, portanto, sem lacunas. Afinal, são obra da razão que se afirma perfeita, capaz de tudo resolver ${ }^{26}$.

E vem, logo a seguir, o Século das Luzes. Recordemos que o Iluminismo é um movimento cultural cuja importância justifica que o constituamos marco temporal que divide duas grandes épocas: um antes e um depois. Marcado pelo racionalismo cujas sementes a Renascença tenha semeado dois séculos antes

\footnotetext{
${ }^{24}$ Vide SANTOS JUSTO, ibidem 39-41.

25 Vide ALMEIDACOSTA, o.c. 342-348; e SANTOS JUSTO, Nótulas de história do pensamento jurídico, cit. 39-41.

${ }^{26}$ Vide ALMEIDA COSTA, o.c. 353-356; e SANTOS JUSTO, Nótulas de história do pensamento jurídico, cit. 41-43.
} 
e só agora florescem, o Iluminismo tem como grandes marcas o laicismo, o naturalismo, o cientismo, o individualismo, o estatismo e o economismo, que rompem com o passado e perspectivam um mundo novo. O Homem volta a ser a medida de todas as coisas, quer compreender os fenómenos naturais, afirmar os valores da liberdade, da igualdade e da propriedade, construir um Estado que garanta a segurança das pessoas e bens num ambiente de paz económica dirigido por uma mão invisível que fará convergir a actuação de todos na realização do equilibro económico ${ }^{27}$.

No plano jurídico, defende-se a lei como única fonte do direito porque, além de expressão da razão e, por isso, geral e abstracta, é segura, certa e clara e constitui um instrumento poderoso de transformação social. Afasta-se o costume porque é incerto e comprometido com o passado que urge transformar. A crença na omnipotência da razão justifica o afastamento da velha opinio communis doctorum, da Glosa de Acúrsio e das opiniões de Bártolo porque não passam de meras probabilidades e a razão pensa que tem acesso à verdade. E, finalmente, afirma-se o direito natural e submete-se o direito romano ao crivo da razão, pelo qual só passa o direito do usus modernus pandectarum ${ }^{28}$.

E especificamente no direito penal e no direito processual penal impôs-se o Humanitarismo com contributos notáveis: a explicação religiosa da pena como expiação é substituída pelas ideias de necessidade e utilidade com expressão na prevenção de todos (prevenção geral) e do próprio delinquente (prevenção especial). As penas corporais são substituídas pela pena de prisão, considerada a regina poenarum. Afirma-se a ideia de proporcionalidade da pena à gravidade do delito. E o respeito pela dignidade humana justifica os princípios in dubio pro reo e nullum crimen sine lege e determina a estrutura acusatória do processo penal. Com base na teoria do contrato social, considera-se que a pena de morte não é necessária nem justa. E combate-se a tortura porque leva à condenação de inocentes débeis e à absolvição de celerados fortes ${ }^{29}$.

É neste ambiente de racionalismo que o Marquês de Pombal realizou as suas reformas que actuaram no direito positivo, na ciência jurídica e no ensino do direito.

Assim, em 1769 a famosa Lei da Boa Razão afastou o costume contra legem e reduziu o direito subsidiário ao direito romano do usus modernus pandectarum ${ }^{30}$ e, em matéria de carácter político, económico, mercantil e marítimo, às leis das nações cristãs, polidas e civilizadas. Ferindo gravemente o costume, aquela lei abriu o caminho para a afirmação da lei como a única fonte do direito ${ }^{31}$.

\footnotetext{
${ }^{27}$ Vide ALMEIDA COSTA, o.c. 359-361; e SANTOS JUSTO, ibidem 47-48.

28 Vide SANTOS JUSTO, ibidem 48.

${ }^{29}$ Vide ALMEIDA COSTA, o.c. 362-364; e SANTOS JUSTO, ibidem 52-53.

30 Sobre o usus modernus pandectatum, vide ALMEIDA COSTA, o.c. 356-358; e SANTOS JUSTO, ibidem 53-54.

31 Vide ALMEIDA COSTA, o.c. 364-371
} 
Volvidos escassos 3 anos, foram promulgados os Estatutos da Universidade de Coimbra que trouxeram uma aragem de progresso ao ensino do direito, introduzindo novas matérias e o método sintético-demonstrativo-compendiário que afastou o velho método escolástico. Doravante, estuda-se mais direito nacional e passaram a ser leccionados o direito natural e a história do nosso direito. Os lentes são obrigados a escrever manuais, breves e claros, para auxiliar os alunos na preparação dos seus estudos, substituindo as velhas postillas, também denominadas sebentas feitas por autores desconhecidos, com erros que importava afastar ${ }^{32}$. A ciência jurídica portuguesa recupera o elevado nível que a distingue e torna credora de admiração. Nível a que não são alheias as lições de grandes Mestres do saber jurídico, de que destacamos Pasqual José de Mello Freire dos Reis, a quem o famoso advogado Manuel de Almeida e Sousa chamou "o nunca assaz louvado Papiniano do nosso Reino"33.

Simplesmente, o Iluminismo tinha lançado ideias muito fortes. A Revolução francesa constitui um exemplo bem significativo. Em Portugal, país de costumes mais brandos, triunfou a Revolução Liberal de 1820 a que se seguiu, dois anos depois, a Independência do Brasil. A história do direito português bifurcou-se, seguindo duas vias: a portuguesa e a brasileira.

Porém, o labor científico não estancou: a doutrina portuguesa ia preparando e facilitando o caminho que António Luís de Seabra iria percorrer na elaboração do primeiro Código Civil Português. E a ciência jurídica brasileira, que durante alguns anos continuou a difundir-se em Coimbra enquanto não se instalou nas jovens Universidades do Brasil, não deixou de pensar numa colectânea que actualizasse as velhas Ordenações Filipinas. Foi o tempo de jurisconsultos da envergadura de CORREIA TELLES, de COELHO DA ROCHA, de TEIXEIRA DE FREITAS e de Cândido MENDES DE ALMEIDA, a que se outros se seguiram, elevando a ciência jurídica de Portugal e do Brasil à excelência que lhe é reconhecida.

\section{A CIVILÍSTICA LUSO-BRASILEIRA DO SÉCULO XIX}

\subsection{Preliminares}

Como referimos, as Ordenações Filipinas continuaram em vigor depois da independência do Brasil, por determinação da Lei de 20 de Outubro de 1823 . No entanto, as necessidades impunham que se fizessem novas compilações, mas a feitura de um Código não é tarefa fácil: é mesmo impossível sem uma ciência jurídica de nível elevado que prepare o campo árduo em que os seus autores vão

32 Vide ALMEIDA COSTA, o.c. 372-377.

33 Vide ALMEIDA COSTA, o.c. 47-48 e 377-380. 
trabalhar. Por isso, e sem esquecer a sábia lição do Padre António VIEIRA de que a omissão é o pior dos pecados, não hesitamos em convocar dois eminentes civilistas de Portugal e do Brasil. Referimo-nos a Manuel António COELHO DA ROCHA e a Augusto TEIXEIRA DE FREITAS.

Ao primeiro, que se doutorou na Faculdade de Leis em $1818^{34}$, e a TEIXEIRA DE FREITAS, que concluiu o Bacharelato em 1837 na Academia de Ciências Sociais e Jurídicas de Olinda ${ }^{35}$, não têm faltado elogios, embora tardios. Em relação a COELHO DA ROCHA já se disse que é "um jurisconsulto de grande envergadura, mesmo no plano mundial", um "Grande Mestre" e um "Sábio"36. E a TEIXEIRA DE FREITAS chamaram "o Cujácio brasileiro"37, "o grande lidador"38 "o maior dos jurisconsultos do tempo"39 e "uma gigantesca figura" .

Une-os a mesma cultura jurídica fortemente apoiada no direito romano ${ }^{41}$, difundida em Coimbra e Olinda; e a circunstância de terem tido um papel decisivo na codificação portuguesa ${ }^{42}$ e brasileira ${ }^{43}$. E separa-os a defesa de posições originais e inovadoras, que a independência dos seus espíritos e as diferentes sociedades justificam.

Impõe-se, ainda, a referência a um aspecto particularmente importante: TEIXEIRA DE FREITAS integra-se na dogmática da Escola Histórica, "com os prestígios de mentalidade e rigor da herança kantiana" 4 . Quanto a COELHO DA ROCHA, embora desconhecesse HUGO, HEISE e SAVIGNY, "preparou, $\grave{a}$ distância, a própria recepção do pandectismo"45.

${ }^{34}$ Vide Fernando José Gautier LUSO SOARES, As instituições de Coelho da Rocha: contributo para a formação do direito civil português moderno. Alguns aspectos (E. do Autor / Lisboa, 1996-1997)14.

35 Vide Levi CARNEIRO, Estudo crítico-biográfico em Código Civil. Esboço, por A. T. de Freitas I (Ministério de Justiça. Departamento de Imprensa Nacional / Brasília, 1983) X; e Sílvio MEIRA, Teixeira de Freitas. O jurisconsulto do império. Vida e obra² (Brasília, 1983) 39.

36 Vide LUSO SOARES, ibidem 14-15.

37 Vide Sílvio MEIRA, Teixeira de Freitas. Ojurisconsulto do império. Vida e obra ${ }^{2}$ (Brasília, 1983) 179; e Haroldo Valladão, Teixeira de Freitas, jurista excelso do Brasil, da América, do Mundo no Código Civil. Esboço, cit. XLVIII;

38 Vide Sílvio MEIRA, o.c. 179.

${ }^{39}$ Vide Levi CARNEIRO, o.c. XXXVII.

40 Vide Orlando de Carvalho, Teixeira de Freitas e a unificação do direito privado no BFD LX (1984)3 e 5.

${ }^{41}$ Em relação a TEIXEIRA DE FREITAS, quando o "taxaram de "nimiamente romanista", acentuou que lhe não poderiam fazer honra maior que essa e que "nas leis e doutrinas do direito romano está depositada toda a filosofia do direito". Vide Levi CARNEIRO, o.c. X-XI. E quanto a COELHO DA ROCHA, basta consultar as suas Instituições de direito civil portuguez ${ }^{8}$ I e II (Livraria Clássica Editora A. M. Teixeira (Lisboa, 1917), onde o Autor manifesta, com frequência, conhecimentos profundos de direito romano. Vide também: Sílvio MEIRA, o.c. 29 e 46.

42 Vide António MENEZES CORDEIRO, Teoria geral do direito civil. Relatório, na RFDL (1988) 115; e Mário Júlio de ALMEIDA COSTA, o.c. 410.

43 Vide Aloísio SURGIK, O pensamento codificador de Augusto Teixeira de Freitas em face da escravidão no Brasil em Roma e América. Collana di Studi Giuridici Latinoamericani (CEDAM / Pádua, 1988) 445.

A. SANTOS JUSTO, O Código de Napoleão e o direito ibero-americano no BFD LXXI (1995) 54-55.

44 Transcrevemos Orlando de CARVALHO, o.c. 73.

45 Transcrevemos MENEZES CORDEIRO, o.c. 115. 
Constrangidos pelo tempo inevitavelmente escasso e pela amplitude do tema seleccionado, justifica-se que limitemos a nossa intervenção a algumas figuras dispersas pelas diferentes áreas das ciências jurídico-civilísticas.

\subsection{PessoA POR NASCER}

TEIXEIRA DE FREITAS define "pessoa por nascer" aquela que, não tendo ainda nascido, já se encontra concebida, ou seja, vive já no útero materno ${ }^{46}$.

Esta figura jurídica foi tutelada no direito romano; e, embora os jurisconsultos romanos entendessem que o conceptus não é ainda pessoa, porque não está "in rerum natura" 47 ou "in rebus humanis" 48 , sendo apenas "mulieris portio vel viscerum" "49 não deixaram de dispensar atenção especial à sua futura humanidade. Assim, a pedido da mãe, podia ser nomeado um curator ventris para defender os interesses do conceptus $^{50}$; a sucessão mortis causa era suspensa até ao nascimento; o testamento em que não fosse instituído herdeiro nem deserdado era inválido; o pater podia nomear-lhe um tutor no seu testamento; e o pretor concedia a posse dos bens hereditários à mulher grávida em nome do concebido ${ }^{51}$.

A partir da casuística romana que remonta à época clássica ${ }^{52}$ foi, na época justinianeia ${ }^{53}$ elaborada a regra qui in utero sunt, in toto paene iure civili intelleguntur in rerum natura esse" ${ }^{\prime 54}$. E foi com base nestes textos que os jurisconsultos medievais elaboraram o princípio conceptus pro iam nato habetur ${ }^{55}$.

TEIXEIRA DE FREITAS distingue pessoas por nascer de pessoas futuras: aquelas existem, porque vivem já no ventre materno; estas, ainda não são pessoas, porque não existem ${ }^{56}$. Depois, insistindo na existência real do conceptus, considera que

46 Vide TEIXEIRA DE FREITAS, Esboço I, cit. 37.

${ }^{47}$ Cf. D. 30,24pr.; GAIUS 2,203.

${ }^{48}$ Cf. D. 38,9,1pr.; $-44,2,7,3$.

${ }^{49}$ Cf. D. 25,4,1,1. O aborto era punido como lesão do corpus matris ou privação da spes prolis do pater. Vide SANTOS JUSTO, A "Fictio iuris" no direito romano ("Actio ficticia"). Época clássica I no suplemento XXXII do BFD (1988) 556.

${ }^{50}$ Cf. D. 26,5,20pr.

${ }^{51}$ Vide SANTOS JUSTO, ibidem 555-556.

${ }^{52}$ Esta época decorre entre os anos 130 a.C. e 230 e caracteriza-se pela perfeição e rigor da ciência jurídica romana, denominada iurisprudentia. O direito romano atinge o seu esplendor, tornando-se um direitomodelo. Vide SANTOS JUSTO, A evolução do direito romano no volume comemorativo do $75^{\circ}$. tomo do $B F D$ (Coimbra, 2003) 53-61.

${ }^{53}$ Esta época situa-se entre os anos 530 e 565 e caracteriza-se pela influência da filosofia helénica (helenismo), pela tendência para imitar o clássico (classicismo) e, sobretudo, pela elaboração do Corpus Iuris Civilis. Vide SANTOS JUSTO, ibidem 67-68.

${ }^{54}$ D. 1,5,26: "Quem está no ventre materno é considerado, em quase todo o direito civil, como nascido".

${ }^{55}$ Vide SANTOS JUSTO, Direito privado romano I. Parte geral (Introdução. Relação jurídica. Defesa dos direitos) $)^{3} \mathrm{em}$ Studia Iuridica 50 /Coimbra Editora / Coimbra, 2006) 108-109.

56 Vide Esboço I, cit. 37. 
as palavras têm sido infiéis ao pensamento, transformando-se a realidade em ficção. E fiel ao seu entendimento de que "não há ente com susceptibilidade de adquirir direitos sem que haja pessoa", considera que o conceptus já existe. Ademais, é representado por um curator denominado ventris e o nada não se representa, mesmo que se diga que a curatela "é mais de bens, que da pessoa"57.

Por isso, propõe a seguinte redacção no art. 221: "Desde a concepção no ventre materno começa a existência visivel das pessoas, e antes de seu nascimento elas podem adquirir alguns direitos, como se já estivessem nascidas". No entanto, propõe, no artigo seguinte: "Esses direitos porém só ficarão irrevogavelmente adquiridos se os concebidos nascerem com vida, isto é, se a manifestarem, ainda que por instantes, depois de completamente separados de sua mãe". E, para clarificar este aspecto, escreve, no art. 225: "Reputar-se-á como certo o nascimento com vida, quando testemunhas presentes ao parto tiverem distintamente ouvido a respiração dos nascidos, sua voz; ou tiverem observado quaisquer outros sinais de vida". Finalmente, TEIXEIRA DE FREITAS entende que não se deve distinguir entre o nascimento espontâneo e o que for obtido por operação cirúrgica; e, como bom romanista, invoca a grande importância desta quaestio que dividiu os jurisconsultos romanos, em virtude dos privilégios atribuídos "à fecundidade das mulheres" 58 .

Manifesta-se, em TEIXEIRA DE FREITAS, a doutrina de SAVIGNY segundo a qual os direitos ficam suspensos até que o nascimento se efectue, embora não aceite a ideia de que "o nasciturus não tem capacidade para adquirir por não ser ainda pessoa" 59 . Depois, afasta a teoria da vitalidade, porque "o filho, uma vez nascido, tem a capacidade de direito a mais completa", não sendo necessário prolongar a sua vida: "se o filho não vital deve(sse) ser reputado como morto, (seria) forçoso reconhecer (...) que não poderia ser objecto de algum delito" ${ }^{60}$.

Dando agora a voz a COELHO DA ROCHA, afirma que pessoa física é o homem, nascido ou embrião (nasciturus, venter, embrio). No entanto, "estes, em tudo o que é do seu interesse, são pelas leis equiparados aos nascidos, e conservam até o nascimento todos os direitos, que lhes competiriam, se estivessem já nascidos no momento em que os adquiriram (...) contanto que nasçam capazes de viver". E considera incapaz de viver "não só o feto, que nasceu morto, ou monstruoso, como também o abortivo, isto é, aquele que nasceu vivo, mas antes do periodo suficiente da gestação, e que por esta causa não pode continuar a viver". Depois, fala das "questões, que se suscitaram sobre ser ou não vital o feto que morreu logo depois de nascido (as quais) só poderão ser decididas por alguns indícios $e$, na falta d'estes, por exame de peritos". E, finalmente, refere "o sábio Autor do

\footnotetext{
57 Vide TEIXEIRA DE FREITAS, ibidem 84-85.

${ }^{58}$ Vide TEIXEIRA DE FREITAS, ibidem 86.

59 Vide TEIXEIRA DE FREITAS, ibidem 85.

${ }^{60}$ Vide TEIXEIRA DE FREITAS, ibidem 86.
} 
Digesto Português (isto é, José Homem CORR A TELLES), que seguiu a regra estabelecida na lei de Touro, segunda a qual "se tinha por abortivo o feto, que morreu dentro em 24 horas depois de nascido". No entanto, "como neste espaço podiam sobrevir outras causas de morte além do defeito de aborto", deixa-nos a sua opinião: "Preferimos a disposição da lei Romana: licet illico decessit)"

Cotejando agora estas posições, logo observamos alguns encontros e desencontros que aproximam e afastam os nossos jurisconsultos.

Observa-se, em TEIXEIRA DE FREITAS, a formação pandectística pelo rigor, assinalada já por Orlando de CARVALHO quando refere a mentalidade e o rigor da herança kantiana ${ }^{62}$. A distinção entre "pessoas por nascer" e "pessoas futuras" constitui um exemplo claro. Depois, as consequências lógicas são irrepreensíveis: aquelas já existem e, por isso, têm direitos e os seus bens podem ser tutelados por um curator ventris; estas não existem. E, se as "pessoas por nascer" já existem, a ficção medieval que os considera como se já tivessem nascido com vista à protecção dos seus direitos é um absurdo. Outra ideia forte é a de que deve considerar-se nascido quem mostrou sinais de vida, ainda que durante um tempo muitíssimo breve: uma simples respiração, um gemido ou outro sinal; e a consequência lógica é igualmente implacável: a recusa da doutrina da vitalidade que exigia que a vida se prolongasse o tempo necessário. TEIXEIRA DE FREITAS parte do direito romano, mas está atento ao tempo em que vive e, por isso, recusa e censura soluções que considera ultrapassadas. Aqui se revela, também, o seu "espírito progressista" que o levou "muitas vezes a desbastar o antigo direito reinícola", nas palavras de Haroldo VALLADÃO ${ }^{63}$.

COELHO DA ROCHA parte da mesma ideia de homem físico sujeito de direitos. Todavia, parece aderir à ideia de ficção, por via da qual o conceptus é equiparado a quem já nasceu e, assim, desencontra-se de TEIXEIRADE FREITAS. Depois, para ultrapassar as dificuldades de morte por causa diferente do "defeito de aborto", manifesta a sua preferência pela regra romana que afasta a vitalidade ("licet illico decessit") e encontra-se com TEIXEIRA DE FREITAS.

Resta saber que tipo de ficção SAVIGNY viu no brocardo conceptus pro iam nato habetur. Entendemos, como UNGER, que não é por se fingir nascido que o conceptus goza de protecção jurídica, mas é por gozar dela que se pode assimilar quem vai nascer a quem já nasceu. Por isso, estamos perante uma linguagem comparativa que evita repetições necessariamente fastidiosas, cansativas e susceptíveis de serem incompletas. E se persistirmos ainda a chamar-lhe ficção, diremos que é puramente dogmática e não histórica ${ }^{64}$.

\footnotetext{
${ }^{61}$ Vide COELHO DA ROCHA, o.c. I, 30-32.

${ }^{62}$ Vide supra, nota 44.

${ }^{63}$ Vide Haroldo VALLADÃO, o.c. XLIV

${ }^{64}$ Vide SANTOS JUSTO, ibidem 559-561.
} 
Resta terminar com a advertência de DEMOGUE: a humanidade actual deve trabalhar para a humanidade futura e, por isso, os sujeitos de direito devem ser tanto as pessoas que vivem como as que vierem a nascer ${ }^{65}$. Separado pelo grande rio a que chamam Oceano Atlântico, TEIXEIRA DE FREITAS parece ter ouvido estas palavras, mas soube evitar excessos, partindo da consideração de que o conceptus é já um ser que vive, embora ainda e somente no ventre materno.

\subsection{Morte CIVIL}

TEIXEIRA DE FREITAS repudia a morte civil que, no seu entendimento, não passa de simples expressão metafórica ou "um nome sem sombra de realidade" ${ }^{\text {"66 }}$. A sua formação romanista e o conhecimento do direito das nossas sucessivas Ordenações, permitem-lhe chegar a esta conclusão. Na verdade, observa que a referência morte civil não aparece nas fontes romanas e refere que foram os intérpretes que a inventaram por dedução da teoria da capitis deminutio. Depois, percorrendo as nossas Ordenações, o Autor nota que aparece nas Ordenações Filipinas ${ }^{67}$ e foi repetida na Carta Régia de 16 de Dezembro de 1615, falando-se de morte natural ou civil "sem que se saiba se uma é consequência da outra ou se são duas penas diversas". E conclui, afirmando que "o mais que se lê em nossos Juristas é obra d'eles e não das nossas leis, salvo o caso da confiscação de bens da Ord. L. $2^{\circ}$., Tit. $26 \S 28$, que fala da perda da vida, ou estado, ou liberdade, e o da Ord. L. $4^{\circ}$., T. $81 \xi 6^{\circ}$. que fala da servidão da pena, privando do direito de testar aos condenados à morte". No entanto, "a confiscação de bens foi abolida pelo art. 20 da Constituição, e assim ficou mutilada aquela Ord. L. $4^{\circ}$. T. $81 \S 6^{\circ}$. e despojada do seu complemento" 68 .

TEIXEIRA DE FREITAS não dispensa a menor simpatia à morte civil e, por isso, no seu Esboço, escreveu, no art. 240, que "termina a existência visível das pessoas pelo seu falecimento". Não surpreendem, portanto, as palavras de Haroldo VALLADÃO que pedimos vénia para transcrever: "Espírito progressista, salientou, ainda, que a legislação civil modelada para uma Monarquia absoluta, sob o predomínio doutras ideias, deve em muitos casos repugnar às condições do sistema representativo. E, por isso, teve muitas vezes que desbastar o antigo direito reinicola, quase a machado, qual fez, por exemplo, com a escravidão, $e$ também com a morte civil"69.

\footnotetext{
${ }^{65}$ Vide René DEMOGUE, Les notions fondamentales du droit privé (Paris, 1911) 351-352.

${ }^{66}$ Vide TEIXEIRA DE FREITAS, Consolidação das leis civis, cit. XCIV-XCV ${ }^{228}$.

${ }^{67} \mathrm{Cf}$. V,120pr; -V,126pr.; -V,126,3.

${ }^{68}$ Transcrevemos TEIXEIRA DE FREITAS, ibidem XCIV-XCV ${ }^{228}$.

${ }^{69}$ Vide Haroldo VALLADÃO, o.c. XLIV. Sobre a posição de TEIXEIRA DE FREITAS perante a escravatura, vide Aloísio SURGIK, O pensamento codificador de Augusto Teixeira de Freitas em face da escravidão no Brasil em Augusto Teixeira de Freitas e il diritto latinoameriacno (CEDAM / Pádua, 1988) 428-431 e 442.
} 
Estas ideias não são partilhadas por COELHO DA ROCHA que discorda também de MELLO FREIRE. Questionando se "os direitos das pessoas acabarão pela morte civil", invoca a Ord. L. 4, tit. 81 § 6 que "expressamente declara que os condenados à morte ficam servos da pena e, portanto, privados de todos os direitos, isto é, mortos civilmente". Nota, depois, a concordância com a Ord. L. 2, tit. $56 \S 28$ e refere a opinião contrária de MELLO FREIRE que, "levado pela sua filantropia e ódio à servidão, julga aquela Ordenação antiquada e inexequível, excepto no caso de ter sido na sentença expressamente declarado que o réu fique privado de todos os direitos, ou morto civilmente". E manifesta a sua opinião: "Apesar de tão respeitável autoridade, nós não achamos inconveniente em sustentar a disposição genérica da Ord., não só por ser terminante e expressa, mas porque achamos ainda a morte civil no art. 818 do novíssimo Código Comercial", além de que é "também admitida na legislação francesa"

$\mathrm{O}$ jurisconsulto português não ignora que a capitis deminutio maxima do direito romano foi abolida pelo Imperador Valentiniano e, depois, por Justiniano; e sabe que a morte civil foi afastada em muitos códigos modernos. Conhece as discussões que tem suscitado, mas questiona: "Quem quer sujeitar-se aos deveres impostos pelas leis sociais, e com os seus crimes perturba a boa ordem da sociedade, com que fundamento se tem de queixar, se o privam das vantagens que lhe eram prometidas pelas leis que ele ofende?" No entanto, declara que "não queremos defendê-la, senão nos termos razoáveis" e, por isso, "não defendemos o efeito da dissolução do matrimónio que o direito francês lhe atribui (...) não só por atacar o vínculo religioso, mas por lançar a nota de impureza sobre o amor dos esposos e a ilegitimidade sobre os seus frutos".

Olhando para estas posições que revelam um profundo desencontro entre os dois jurisconsultos, há, em TEIXEIRA DE FREITAS, uma atitude reveladora de um jurisconsulto a quem o futuro iria dar razão. Não devemos, porém, ignorar o palco social em que ambos actuavam: o Brasil vivia dias pacíficos, bem longe das perturbações francesas que tinham chegado a Portugal. Por isso, talvez se compreenda a posição de COELHO DA ROCHA que, no entanto, procura afastarse do rigor do direito francês, sustentando que os efeitos da morte civil não devem atingir o santuário das relações familiares.

${ }^{70}$ Vide COELHO DA ROCHA, o.c. I, 247. 


\subsection{LEGITIMAÇÃO POR MATRIMÓNIO SUBSEQUENTE}

No direito romano da época pós-clássica ${ }^{71}$ foi criada esta modalidade de legitimação com a finalidade de reduzir o número de concubinatos. Mais rigorosamente, foi instituída pelo Imperador Constantino no ano 335, com carácter transitório: apenas para legitimar os filhos naturais nascidos (de relações (estáveis) de concubinato) nesse ano. Mais tarde, no ano 517, por efeito de uma constitutio de Anastácio adquiriu carácter geral: passaram a poder ser legitimados todos os filhos naturais nascidos em qualquer ano. No direito de Justiniano, esta forma de legitimação dependia dos seguintes requisitos: a) a mãe devia ser livre; b) no momento da concepção, o matrimónio dos pais devia ser possível; c) o filho devia consentir ou, pelo menos, não se opor; d) o casamento devia ser registado ${ }^{72}$. De fora, ficavam os filhos de ligações proibidas, denominadas coito danado, como o incesto, o adultério e o estupro.

O direito canónico seguiu fundamentalmente o direito romano, mas estendeu a legitimação per subsequens matrimonium aos filhos de estupro e de adultério, se entre os pais não houvesse o impedimento criminis.

Os nossos praxistas do século XVII seguiram esta posição, enquanto, naAlemanha, se tinha estendido aquela forma de legitimação a todos os filhos de coito danado, desde que os pais obtivessem autorização para casar. A doutrina alemã manteve esta orientação no século XVIII, acolhida, entre nós, por MELLO FREIRE e LOBÃO, que a consideraram "mais favorável aos filhos (e) mais própria a emendar os erros dos pais"73.

Anos depois, COELHO DA ROCHA aderiu a esta doutrina. Todavia, perante o obstáculo literal das Ordenações Filipinas ("com tanto que este filho fosse tal, que com Direito podesse ser legitimado por seguinte matrimonio") ${ }^{74}$ que exclui a generalidade da legitimação per subsequens matrimonium, "dando a entender que há filhos que podem ser legitimados e outros que não", o nosso jurisconsulto entende que "não levamos contudo o escrúpulo até ao ponto de respeitar como decisivo o argumento tirado das palavras incidentes de uma lei antiga, enunciadas conforme as ideias desse tempo", além de que "poderemos ainda desculpar-nos com a incúria dos Filipistas". E, finalmente, invoca o respeito pelas providências e cláusulas pontifícias nestas matérias, "onde o espiritual está tão intimamente ligado com o civil, que não é fácil extremar os limites de um e outro"75.

\footnotetext{
${ }^{71}$ Esta época decorre entre os anos 230 e 530 e caracteriza-se pela confusão (de terminologia, de conceitos, de instituições e até de textos) que se acentua, no Ocidente, a partir do ano 395 com a divisão definitiva do Império, vulgarizando o direito romano. Vide SANTOS JUSTO, A evolução do direito romano, cit. 61-67.

72 Vide SANTOS JUSTO, Direito privado romano IV (Direito da família) 30-31. Aguarda-se, para breve, a sua publicação em Studia Iuridica.

${ }^{73}$ Vide COELHO DA ROCHA, o.c. 269-270.

${ }^{74}$ Cf. Ordenações Filipinas II,35,12.

75 Transcrevemos COELHO DA ROCHA, o.c. 270.
} 
Por sua vez, TEIXEIRADE FREITAS, escreveu, no art. 215 da Consolidação das Leis Civis, que "o filho legitimado por seguinte matrimónio entre seu pai e mãe depois do nascimento, feito em face da Igreja, ou fora dela por licença do Prelado, reputa-se perfeitamente legítimo, como se ao tempo do nascimento já o matrimónio fosse celebrado" E, no art. seguinte, escreveu: "Verifica-se a legitimação por subsequente matrimónio, quando o filho é tal, que por Direito pode ser assim legitimado". Questionando, depois, sobre "quais são esses filhos que podem ser legitimados por seguinte matrimónio, o jurisconsulto brasileiro aponta o silêncio das Ordenações Filipinas e a divergência dos intérpretes e entende que "a Ord. exclui a generalidade e não se lhe pode atribuir a amplitude do Direito Canónico" E justifica: "Se a lei, em favor do casamento e da legitimidade, pode cobrir o vício do nascimento de um filho e oferecer meio de repará-lo, não deve contudo sancionar a obra do adultério, e do incesto". E termina: "Que serviço matar esta famosa questão com um rasgo de pena!"76.

A opinião de TEIXEIRA FREITAS mantém-se no Esboço, em cujo art. 1601, escreve: "Proíbe-se que filhos de coito danado 77 sejam reconhecidos por seu pai ou mãe e também se proíbe que a respeito da paternidade ou maternidade deles se provoque em juízo qualquer investigação especial'. Há, no entanto, uma ligeira excepção, consagrada no art. 1602: "Todavia, se houver sentença passada em julgado que faça certa a filiação de coito danado, esses filhos só terão direito para exigir de seu pai, ou mãe, a prestação de alimentos e nenhum outro direito lhes competirá". O Autor tinha em vista o filho de casamento contraído de má fé posteriormente anulado por bigamia ou incesto; quando o filho de mulher casada não fosse considerado filho do marido; e quando uma sentença, insusceptível de ser reformada, tivesse, por erro de facto ou de direito, admitido investigação de paternidade de que resultasse a verificação de uma filiação de coito danado ${ }^{78}$.

Estamos perante a possibilidade de um matrimónio subsequente legitimar os filhos nascidos anteriormente: é fundamental, que o matrimónio seja celebrado e, portanto, que não haja impedimento. Afastada está, assim, a possibilidade de um filho incestuoso poder ser legitimado por esta via.

Nos casos em que o matrimónio é legalmente possível, estamos perante posições desencontradas: COELHO DA ROCHA é, nesta matéria delicada, mais progressista, estendendo a legitimação per subsequens matrimonium a todos os filhos de coito danado. Segue a orientação já perfilhada por MELO FREIRE e LOBÃO que procurava não penalizar esses filhos por erros dos pais. Já TEIXEIRA DE FREITAS

\footnotetext{
76 Transcrevemos TEIXEIRA DE FREITAS, Consolidação das leis civis, cit. 160-162.

77 Art. 171 do Esboço: "São filhos de coito danado somente os adulterinos, os incestuosos e os sacrílegos (filhos de pai clérigo de ordens maiores ou de pessoa, pai ou mãe, ligada por voto solene de castidade em Ordem Religiosa aprovada pela Igreja Católica).

78 Vide TEIXEIRA DE FREITAS, Esboço I, cit. 323.
} 
é intransigente, enfatizando a obra do adultério que não deve ser reparada. O primeiro privilegia o interesse dos filhos; o segundo, os valores que condenam o adultério. Dirse-á que, nesta matéria, o futuro deu razão a COELHO DA ROCHA.

\subsection{PrescriçÃo AQUisitiva TRINTENÁRIA}

No direito romano, o Imperador Constantino concedeu ao possuidor a faculdade de contestar, por exceptio (denominada longissimi temporis praescriptio), a acção de reivindicação do proprietário, no caso de a posse durar, pelo menos, 40 anos, dispensando o justo título e a boa fé. Aquele expediente tinha, apenas, a função de paralisar esta acção. Mais tarde, no ano 424, Teodósio II reduziu o tempo para 30 anos e atribuiu-lhe uma dupla função: extintiva da acção; e aquisitiva de um direito, sem necessidade de título. Depois, Justiniano manteve a dispensa do título, mas exigiu a boa fé no início da posse ${ }^{79}$.

O direito canónico seguiu o direito romano, mas exigiu que o possuidor estivesse de boa fé, porque lhe pareceu ofensivo da moral que pudesse adquirir a propriedade de uma coisa sabendo, ou pelo menos desconfiando, que não the pertencia; e determinou que a boa fé devia existir não só no início, mas também durante todo o tempo da posse ${ }^{80}$.

As nossas Ordenações acolheram a orientação do direito canónico. Com a devida vénia, transcrevemos:

Ordenações Afonsinas (II,9,1): “E acontecendo que, acerca de tal caso as Leis Imperiais sejam contrárias aos Cânones, mandamos que assim nas coisas temporais como espirituais, se guardem os Cânones, se o caso for tal que guardando as Leis Imperiais traga pecado; pode-se pôr exemplo no possuidor de má fé que, segundo as Leis Imperiais, por trinta anos possuindo sem título, prescreve a coisa alheia, e segundo o Direito Canónico o possuidor de má fé não pode prescrever por nenhum tempo; se, em tal caso, se guardassem as Leis Imperiais, guardando-as, necessariamente traria pecado ao possuidor, o que não devemos consentir, maiormente que em tal caso devemos necessariamente obediência ao Padre Santo e à Santa Igreja, de que os Cânones procedem, a qual não devemos em nenhum caso aos Imperadores, de que as Leis Imperiais procedem (...) e no caso temporal, que a guarda das Leis Imperiais não traga pecado, elas devem ser guardadas, não embargante que os Cânones sejam em contrária disposição”.

Ordenações Manuelinas (II,5pr.): “...E quando o caso de que se trata não for determinado por Lei, Estilo ou Costume do Reino, mandamos que

${ }^{79}$ Vide SANTOS JUSTO, Direito privado romano III (Direitos reais), reimpressão, em Studia Iuridica 26 (Coimbra Editora / Coimbra, 1997) 88-89.

${ }^{80}$ Vide COELHO DA ROCHA, o.c II, 602-603. 
seja julgado, sendo matéria que traga pecado, pelos Santos Cânones; e sendo matéria que não traga pecado, mandamos que seja julgado pelas Leis Imperiais, posto que os Sacros Cânones determinem o contrário, as quais Leis Imperiais mandamos somente guardar pela boa razão em que são fundadas".

As Ordenações Filipinas repetem literalmente esta disposição e, por isso, justifica-se que as não transcrevamos ${ }^{81}$.

Pode, assim, concluir-se que os nossos tribunais não aplicavam subsidiariamente o direito romano na integração destas lacunas; recorriam, sim, ao direito canónico, por força do qual o possuidor de má fé não adquiria a propriedade da coisa possuída, mesmo que a sua posse durasse 30 anos.

Entretanto, a Lei de 18 de Agosto de 1769, crismada de boa razão por CORR A TELLES 82 , ordenou que a "suposição de pecado, como motivo das leis pátrias, se haja por não escrita" $"$, permitindo que COELHO DA ROCHA sustentasse que "necessariamente havemos de dar por antiquado, e sem execução, o último período da mesma Ordenação sobre a má fé, como disposição sem fundamento" ${ }^{4}$.

Quanto a TEIXEIRA DE FREITAS, observamos o que escreveu no art. 1321 da Consolidação das Leis Civis: "O possuidor de má fé em tempo nenhum poderá prescrever". É um efeito lógico da sua opinião sobre a boa fé: '"é a alma do comércio, que não pode subsistir sem ela".

Se o jurisconsulto brasileiro não mudou de opinião, poder-se-á dizer que, também aqui, o futuro deu razão a COELHO DA ROCHA.

\subsection{EFEITOS DA COMPRA E VENDA}

No direito romano da época clássica ${ }^{85}$, o contrato de compra e venda (emptiovenditio) criava para o vendedor a obrigação de transferir, ao comprador, a posse livre e pacífica da coisa vendida e de lhe assegurar o seu gozo pacífico; por sua vez, o comprador obrigava-se a pagar ao vendedor o preço em pecunia determinada. Garantida a posse, o comprador tornar-se-ia proprietário por usucapião, decorridos dois ou um ano, respectivamente, se a res fosse mancipi ou nec mancipi. Antes, porém, a propriedade poder-se-ia transferir através de negócio jurídico idóneo, como a mancipatio ou a in iure cessio. Entretanto, se o comprador fosse demandado por terceiro que afirmasse ser proprietário da coisa vendida, o vendedor respondia

\footnotetext{
${ }^{81}$ Cf. Ordenações Filipinas III,64,pr.

${ }^{82}$ Vide ALMEIDA COSTA, o.c. $366^{1}$.

${ }^{83}$ Cf. $\S 12$ da Lei de 18 de Agosto de 1769.

${ }^{84}$ Vide COELHO DA ROCHA, o.c. II, 605.

${ }^{85}$ Vide supra, nota 52.
} 
por evicção se recusasse participar no processo ou o comprador fosse condenado a entregar a coisa ao demandante. Esta responsabilidade, calculada no dobro do valor da res, cessava depois da usucapião, porque, permitindo a aquisição ao comprador, implicava a perda da propriedade do antigo proprietário ${ }^{86}$.

Enquanto o vendedor não entregasse a res ao comprador, este respondia pelo risco (periculum), apesar de aquele ser o proprietário: não podendo invocar a regra res suo domino perit, invocava-se outra: debitor rei certae eius interitu liberatur.

Entretanto, na época pós-clássica ${ }^{87}$, mais precisamente no ano 293, os Imperadores Constâncio e Maximiano determinaram que o domínio das coisas se transfere por tradição e por usucapião e não por simples pacto ${ }^{88}$. Ou seja, a tradição, que o vendedor se obrigava a realizar, deixava de transferir a posse, para transferir a propriedade. Na base deste sistema (modernamente denominado) do título e do modo está a ideia de que o domínio só por abstracção se pode separar da posse ${ }^{89}$.

Ainda nessa época, foi introduzido, por influência dos direitos de algumas províncias do Oriente, o princípio de que a propriedade se transfere por efeito do contrato de compra e venda. Este princípio terá sido inicialmente consagrado pelo Imperador Constantino e sucessivamente reafirmado, primeiro em situações específicas e, depois, com alcance geral. Ao mesmo tempo, impôs-se o princípio de que o pretium devia ser pago como condição da transferência da propriedade: na sua ratio está a circunstância de se viver num período de acentuada desvalorização monetária que sugeria que o vendedor fosse imediatamente pago ${ }^{90}$.

Finalmente na época justinianeia ${ }^{91}$, observa-se um regresso ao regime clássico: a compra e venda volta a produzir efeitos obrigacionais, cumprindo o vendedor a sua obrigação de transferir o domínio da res vendida através de uma traditio que substituiu os velhos negócios jurídicos da mancipatio e da in iure cessio. No entanto, manteve-se o requisito pós-clássico que impôs a necessidade do pagamento do preço ${ }^{92}$.

Passando ao nosso direito, verificamos que as sucessivas Ordenações seguiram o regime jurídico romano da compra e venda da época justinianeia. Transcrevemos as Ordenações Filipinas:

\footnotetext{
${ }^{86}$ Vide SANTOS JUSTO, Direito privado romano II (Direito das obrigações) ${ }^{2}$ em Studia Iuridica 76 (Coimbra Editora / Coimbra, 2006) 49-63.

87 Vide supra, nota 71.

${ }^{88}$ C. 2,3,20: "Traditionibus et usucapionibus dominia rerum, non nudis pactis transferuntur".

89 Vide COELHO DA ROCHA, o.c. II, 649.

${ }^{90}$ Vide António A. VIEIRA CURA, O fundamento romanístico da eficácia obrigacional e da eficácia real da compra e venda nos códigos civis espanhol e português em Studia Iuridica 70 Colloquia 11. Jornadas romanísticas (Coimbra Editora / Coimbra, 2003 81-95.

91 Vide supra, nota 53.

92 Vide VIEIRA CURA, o.c. 95-101.
} 
IV,7pr. "Se o que for senhor de alguma coisa a vender duas vezes a desvairadas pessoas, o que primeiro houver a entrega dela será dela feito verdadeiro senhor, se dela pagou o preço por que lhe foi vendida...".

IV,7,1: "E se o senhor da coisa a vendesse a alguém por preço certo e lha entregasse logo, sem dele receber preço algum e depois o vendedor recuperasse a posse dela e a vendesse a outro e lha entregasse recebendo dele o preço, este segundo comprador será feito cumpridamente senhor dela". IV,7,2: "E se o senhor da coisa a vendesse a alguém, e recebesse o preço sem lha entregar, e depois a vendesse a outrem e lha entregasse, recebendo dele o preço, ou havendo-se dele por pago, este segundo comprador será feito verdadeiro senhor dela e o primeiro comprador poderá demandar ao vendedor o dinheiro que lhe pagou por a compra da dita coisa com seu interesse, pois lhe não entregou a coisa que lhe vendeu, de que recebeu o dinheiro, e a vendeu a outrem e o fez dela senhor pela entrega que dela fez...”.

Quanto ao risco, as nossas Ordenações voltam a consagrar a doutrina do direito romano. Voltamos a transcrever as Ordenações Filipinas:

IV, 8pr: "Tanto que a venda de qualquer coisa é de todo perfeita, toda a perda e perigo que dai em diante acerca dela aconteça, sempre acontece ao comprador, ainda que a perda e dano aconteça antes que a coisa seja entregue...".

Ou seja, se a coisa vendida for destruída ou perecer, o vendedor fica liberado da sua obrigação, mas conserva a acção contra o comprador pelo preço, "por ser devedor duma quantidade e esta nunca perece" ${ }^{" 93}$.

Apreciando os primeiros textos das Ordenações Filipinas, COELHO DA ROCHA refere que "é necessário reconhecer que na praxe as mais das vezes (a exigência da traditio) não se poderá aplicar: porque em tais contratos entre nós, quando são feitos por escrito, costuma geralmente inserir-se a declaração de que o vendedor transfere desde logo ao comprador todo o domínio (...) e esta cláusula não é uma simples redundância tabeliôa; tem o efeito importante de não deixar o domínio para a tradição o qual se deve atender e respeitar" ${ }^{\prime 94}$.

Esta posição manifesta alguma simpatia pelo modelo francês da transferência da propriedade por efeito do contrato de compra e venda. Igual simpatia se observa quando, pronunciando-se sobre o risco que onera o comprador mesmo antes da traditio da coisa vendida, COELHO DA ROCHA afirma que "é mui dura e injusta, enquanto neste caso liberta o vendedor da sua obrigação e não o comprador". $\mathrm{E}$, por isso, considera "muito mais razoáveis, neste ponto, as disposições dos

${ }^{93}$ Transcrevemos COELHO DA ROCHA, o.c. II, 651.

${ }^{94}$ Vide COELHO DA ROCHA, O.C. II, 556. 
códigos alemães (...) que adoptaríamos se tratássemos de iure constituendo", pois, segundo estes, "se a coisa certa pereceu antes da entrega, fica sem efeito a compra e, portanto, o comprador pode repetir o preço, se já tinha pago" 95 .

Posição diferente é a de TEIXEIRA DE FREITAS que se insere na orientação romanista acolhida nas nossas Ordenações. Com efeito, os artigos que escreveu na Consolidação das Leis Civis e no Esboço e os comentários que fez não suscitam dúvidas. Transcrevemos:

1. Consolidação das Leis Civis:

- art. 534: "Vendida a mesma coisa a duas diferentes pessoas, prefere o comprador a quem primeiro se fez a entrega; se a esta acedeu o pagamento do preço ou o vendedor se deu por pago";

- art. 535: "O primeiro comprador, que chegou a pagar o preço ao vendedor e que é preferido pelo segundo comprador a quem a coisa foi entregue tem direito para demandar a restituição do preço pago e seus juros e para acusar o vendedor por estelionato".

2. Esboço:

- art. 1971: "Haverá compra e venda, quando, para o fim de transferir domínio, uma das partes se tiver obrigado a entregar uma coisa com valor por si, e a outra parte a pagar-lhe por essa coisa um preço em dinheiro"; - art. 2023: "Fica obrigado o vendedor: $1^{\circ}$. - a conservar a coisa vendida até que a entregue ao comprador...; $2^{\circ}$. - a entregar ao comprador a coisa vendida no tempo ajustado ..."

Estes artigos são corroborados com os seus comentários. Destacamos: "sem a tradição não há transferência de domínio". Porém, se a venda for de imóveis, "transcrita no Registo Geral (...), a tradição se reputa feita para o comprador produzindo a venda seus efeitos a respeito de terceiros desde a data da transcrição" 96 .

Na mesma época, TEIXEIRA DE FREITAS defendeu intransigentemente a nossa velha tradição jurídica, censurando o Autor do Código Civil português de 1867 por, seguindo o modelo francês de que a propriedade se transfere apenas por efeito do contrato, ter descaído num mundo fictício ${ }^{97}$. O jurisconsulto brasileiro foi particularmente contundente, afirmando que "o rápido exame que logo fizemos do Projecto do Código Civil Português foi para nós uma decepção tremenda"; e fala mesmo do "abandono de todas as tradições, de todos os costumes e hábitos nacionais" $"$.

\footnotetext{
95 Voltamos a transcrever COELHO DA ROCHA, o.c. II, 651.

96 Vide Consolidação das leis civis, cit. 303.

${ }^{97}$ Vide SANTOS JUSTO, O Código de Napoleão e o direito ibero-americano, cit. 41.

${ }^{98}$ Vide Sílvio MEIRA, o.c. 171-175.
} 
Quanto ao risco, onera o comprador, se a coisa vendida for certa e individualmente determinada ${ }^{99}$. Ou seja, mantém-se acriticamente a solução romana consagrada nas nossas Ordenações.

É fácil observar, aqui, um grande desencontro de ideias que afasta TEIXEIRA DE FREITAS de COELHO DA ROCHA: o primeiro defende, por vezes com entusiasmo desmedido, a nossa longa tradição jurídica; o segundo sacrifica-a, de iure constituendo, optando por outro regime jurídico.

\title{
2.7 O PRINCÍPIO NEMO PRO PARTE TESTATUS
}

\section{pro parte intestatus decedere potest}

Segundo o direito romano, uma das condições de validade dos testamentos era a instituição de herdeiro, exactamente por ocupar o lugar deixado vago pelo de cuius $^{100}$. Em consequência, e exceptuando os militares, ninguém podia falecer em parte com testamento e em parte sem testamento, ou seja, não podia haver concurso de herdeiros testamentários e legítimos: aqueles afastavam estes; e se o testamento fosse nulo por falta de herdeiro, a herança considerava-se legítima.

Este sistema foi acolhido nas Ordenações Filipinas que, com a devida vénia transcrevemos:

\begin{abstract}
IV,82pr.: "Se o pai ou mãe fizerem testamento e, sabendo que tem filhos ou filhas, tomarem a terça de seus bens e a deixarem a quem lhes aprouver ou mandarem distribuir depois de suas mortes, como for sua vontade, posto que no testamento não sejam os filhos expressamente instituídos herdeiros ou deserdados, mandamos que tal testamento valha e tenha efeito. Porquanto, pois, tomou a terça de seus bens no testamento e sabia que tinha filhos, parece que as duas partes quis deixar aos filhos e os instituiu nelas posto que delas não faça expressa menção e assim devem ser havidos por instituídos herdeiros, como se expressamente o fossem, em favor do testamento".
\end{abstract}

Como se observa, para salvar a validade de um testamento feito sem a instituição de herdeiro, o legislador filipino considera-o tacitamente instituído. Todavia, a lei de 18 de Agosto de 1769 (Lei da Boa Razão) ${ }^{101}$ determinou que, na integração das lacunas, se devia recorrer ao direito romano somente se estivesse de acordo com a boa razão e afastou expressamente, no seu preâmbulo, a regra

\footnotetext{
99 Cf. arts. 537 e $538 \S \S 2^{\circ}$. e $3^{\circ}$. da Consolidação das leis civis; e art. 2024 do Esboço

${ }^{100}$ Cf. I. 2,23,2; GAIUS 2,248. Vide Sebastião CRUZ, Direito romano, cit. 228.

${ }^{101}$ Vide supra, a nota 49.
} 
nemo pro parte testatus pro parte intestatus decedere potest. Portanto, foi revogado o sistema romano consagrado nas nossas Ordenações ${ }^{102}$.

COELHO DA ROCHA acolheu a nova orientação ${ }^{103}$ que abalou a nossa tradição jurídica. Entretanto, no Brasil, TEIXEIRA DE FREITAS redigia a sua Consolidação das Leis Civis, dispondo:

- art. 1009: "Se o testador, sabendo que tinha herdeiros necessários, não os instituir expressamente nem deserdar, dispondo somente da terça, há uma instituição tácita e valerá o testamento quanto à disposição da terça";

- art. 1010: "Se o testador dispuser de toda a herança preterindo os herdeiros necessários, de cuja existência sabia, o testamento será nulo quanto à instituição, mas serão válidos os legados que couberem na terça".

As referências a herdeiros necessários ${ }^{104}$, e à terça, quota disponível oriunda do direito muçulmano, mostram a formação romanista e o conhecimento da nossa história jurídica por parte de TEIXEIRA DE FREITAS. A sua posição, coincidente com a de COELHO DA ROCHA, revela igualmente que estava atento à necessidade de transformar o direito para resolver problemas que reclamam outras soluções. Há, aqui, um encontro de posições.

\subsection{LOCAÇÃO DE COISA}

No direito romano, a locação de coisa (locatio-conductio rei) era um contrato consensual, por efeito do qual o locador se obrigava a pôr à disposição do locatário a res prevista para ser usada durante determinado tempo, mediante o pagamento de uma renda denominada merces. Quanto ao risco, se entrassem na sorte normal do contrato, onerava o locatário; tratando-se de acontecimentos anormais, era suportado pelo locador, mas o locatário era liberado do pagamento da renda.

Considerava-se risco normal uma tempestade que destruiu os frutos ou a afectação grave de uma colheita por inundações, aves (gaios, estorninhos), incursões de inimigos, carvão, calor anormal, terramotos, incêndios, etc. Nestas situações, o locatário podia ser dispensado do pagamento da renda, mas se, nos

${ }^{102}$ Vide COELHO DA ROCHA, o.c. II, 479. Segundo o Autor, "suposto que grande número dos $\S \S$ desta Lei foram suspensos pelo Decreto de 17 de Julho de 1778, nesta suspensão não foi compreendido o preâmbulo nem, por conseguinte, os princípios gerais que nele se contêm".

${ }^{103}$ Vide COELHO DA ROCHA, o.c. II, 478-479.

${ }^{104}$ No direito romano, os herdeiros necessários não podiam recusar a herança; por isso, a própria morte do de cuius os fazia herdeiros. Eram herdeiros necessários os heredes sui (filhos, filhas, esposa sujeita ao poder marital (uxor in manu) e os netos e netas, filhos ou filhas de um filho pré-falecido) e os escravos libertados no testamento e nesse testamento instituídos herdeiros. Vide Sebastião CRUZ, o.c. 229. 
anos seguintes, houvesse colheita abundante, o locador seria compensado, podendo exigir a parte da renda que não recebeu no ano anterior. Do mesmo modo, se a colheita de um ano fosse gravemente afectada por aqueles acontecimentos, mas, nos anos anteriores tivesse sido satisfatória, o locatário nada poderia reclamar, porque os anos bons compensam os maus ${ }^{105}$.

Se a coisa locada fosse vendida, o comprador não estava vinculado a manter a relação locatícia estabelecida entre o vendedor-locador e o locatário. Trata-se do célebre princípio emptio tollit locatum que se apoia na natureza obrigacional da locatio-conductio: sendo terceiro, o comprador é estranho à locação que, por isso, não o vincula ${ }^{106}$. O regime jurídico romano foi consagrado nas nossas Ordenações que, no entanto, o restringe a locações com menos de 10 anos ${ }^{107}$.

Perante estas disposições legais, COELHO DA ROCHA observa: "Não negamos que a este rigor do sistema se sacrificou, neste caso, o respeito à boa fé, debaixo do qual o condutor (locatário) contraiu". Por isso, acrescenta: "Se tratássemos de iure constituendo, não duvidaríamos estabelecer a regra inversa, como se acha no Código Civil Francês" ${ }^{108}$.

Por seu lado, TEIXEIRA DE FREITAS escreve, na Consolidação das Leis Civis, que "o comprador da coisa alugada ou arrendada não é obrigado a respeitar a locação feita pelo vendedor e pode despejar o locatário" 109 . Recusa esta faculdade "se o comprador se obrigou, no contrato de compra e venda, a respeitar a locação ou se, depois, consentiu na conservação do locatário por qualquer modo" 110 . Quanto ao risco, tratando-se de prédios frutíferos, "o arrendatário fica desobrigado de pagar a renda anual, se os frutos se perderem completamente por caso insólito, como o de inundação, incêndio, seca, invasão de inimigos e outros semelhantes" 111 . Porém, "se nos outros anos do arrendamento, antes ou depois do ano estéril, a produção for extraordinariamente abundante, guardar-se-á o disposto no Direito Comum " ${ }^{112}$ ou seja, no direito romano.

Mais tarde, no Esboço, o jurisconsulto brasileiro escreveu, no art. $2477 \S 6^{\circ}$. que "resolve-se a locação de tempo determinado pela alienação total que dela fizer o locador, ou transferência que fizer de seu direito real sobre ela ou por constituir

${ }^{105}$ Cf. C. 4,65,8. Vide SANTOS JUSTO, A locatio-conductio rei (direito romano) no BFD LXXVIII (2002) 27.

106 Vide SANTOS JUSTO, ibidem 31.

${ }^{107}$ Outras excepções, agora romanas, são também consagradas: não ter sido acordado entre o vendedor e o comprador em que este cumpra a locação; ou se, depois da venda, o comprador outorgou ou consentiu que fosse cumprido o contrato de locação; ou se o vendedor, no contrato de locação obrigou a coisa locada em relação ao cumprimento do contrato. Cf. Ordenações Filipinas IV,9.

108 Transcrevemos COELHO DA ROCHA, o.c. II, 570.

${ }^{109}$ Cf. art. 655.

${ }^{110}$ Cf. art. $656 \S \S 1$ e a 3.

111 Cf. art. 657.

${ }^{112}$ Cf. art. 659. 
ela algum direito real incompativel com o uso ou gozo do locatário, se também o adquirente não for obrigado a respeitar a locação e não respeitá-la".

Embora conheça a solução contrária do direito francês em relação à venda da coisa locada, TEIXEIRA DE FREITAS não se afasta da tradição portuguesa. Por isso, se compararmos a sua posição com a doutrina de COELHO DA ROCHA, a simpatia deste pelo direito francês afasta os dois jurisconsultos. Será que o futuro deu razão a COELHO DA ROCHA ? A resposta não pode deixar de ser afirmativa em relação ao direito português. Mas também não é inteiramente negativa se nos referirmos ao direito brasileiro. Todavia, as diferentes condições sociais e económicas reclamavam soluções e pontos de vista diferentes.

\subsection{RELAÇÕES PATRIMONIAIS ENTRE CÔNJUGES: O REGIME DE COMU- NHÃO GERAL DE BENS}

Já referimos, em traços mui breves, a história dos regimes patrimoniais de bens doa casamentos celebrados em Portugal e no Brasil. Mas, porque ficámos nas Ordenações Filipinas, é tampo de prosseguir.

No século XIX, época fortemente marcada pelo Código Civil francês que consagrou como regime regra, a comunhão de adquirido ${ }^{113}$, importa não ignorar as posições coincidentes de COELHO DA ROCHA e de TEIXEIRA DE FREITAS que manifestam, nesta área particularmente sensível, o respeito pela nossa tradição jurídica.

Com efeito, na sua Consolidação das Leis Civis, o insigne jurisconsulto brasileiro escreve que "os esposos podem excluir a comunhão de bens, no todo ou em parte; e estipular quaisquer pacto e condições, devendo-se guardar o que entre eles for contratado" 114 . Ou seja, defende-se, como supletivo, o regime da comunhão geral de bens que, observa TEIXEIRA DE FREITAS, constitui "o costume geral do Império" 115 . Todavia, "estes contratos só podem ser feitos antes do casamento ${ }^{116}$; $\mathrm{e}$ se "os cônjuges, (...) contrata(ram) antes do casamento em contrário ao regime da comunhão recíproca de bens (, podem) resilir de suas preexistentes estipulações" 117 . Como suporte desta doutrina, TEIXEIRA DE FREITAS invoca que " $a$ comunhão tácita universal de bens no casamento representa neste a perfeita unidade dos casados". Prossegue, citando RIBAS: "O homem solteiro é um ente incompleto, é pela união com a mulher que ele se completa". E, invocando LAFFAYETTE, refere

\footnotetext{
${ }^{113}$ Cf. arts. 1400 e ss.

${ }^{114} \mathrm{Cf}$. Art. 88.

${ }^{115}$ Vide TEIXEIRA DE FREITAS, Consolidação das Leis Civis, cit. $80^{16}$.

${ }^{116}$ Vide TEIXEIRA DE FREITAS, ibidem $80-81^{17}$.

${ }^{117}$ Vide TEIXEIRE DE FREITAS, ibidem $81^{17}$.
} 
que "a comunhão universal de bens reproduz no mundo material a identificação da vida e destinos dos cônjuges"

Encontramos a mesma posição em COELHO DA ROCHA, embora, pensamos, sem o entusiasmo do jurisconsulto brasileiro. Na verdade, o jurista português limita-se a invocar as Ordenações Filipinas e alguns Códigos modernos. Refere que "o fim do matrimónio pode muito bem obter-se seja qual for o regímen, isto é, a forma, por que se regule a fortuna dos cônjuges; porque não tem com ela relação, senão indirecta, e mui remota" "119. Mas não deixa de observar, na comunhão legal dos bens entre os cônjuges, uma "sociedade universal (que é) mais análoga à união e intimidade característica do matrimónio" ${ }^{120}$; e, na presunção que estabelece, a lei é "coerente com o princípio da igualdade"121.

Numa brevíssima apreciação, poder-se-á dizer que os dois jurisconsultos tinham razão no seu tempo que durou mais no direito brasileiro: em Portugal, o velho regime foi afastado no Código Civil de 1966; no Brasil, a sua vigência prolongou-se até à Lei $n^{\circ}$. 6.515, de 26 de Dezembro de $1977^{122}$. No entanto, bastou uma década para que os nossos direitos convergissem porque razões, como o golpe de baú, não são exclusivas de nenhum país.

Voltaremos, no entanto, a este tema.

\subsection{Plantação e frutos de ÁrVores Situadas Perto da li- NHA DIVISÓRIA}

No direito romano, influenciado pelas leis de Sólon, o proprietário de um fundus devia recuar 9 ou 5 pés, se quisesse plantar, respectivamente, oliveiras e figueiras e outras árvores ${ }^{123}$. Mesmo assim, se os frutos caíssem, por acção da chuva ou do vento, no prédio vizinho, a Lei das XII Tábuas ${ }^{124}$ concedeu ao dominus arboris a faculdade de aí penetrar para os recolher. Posteriormente, o pretor determinou que a entrada podia ocorrer em dias alternados. $\mathrm{O}$ vizinho não podia impedi-la, mas gozava da faculdade de exigir uma caução (cautio damni infecti) que garantia os danos que eventualmente fossem causados ${ }^{125}$.

Por outro lado, aquela lei concedeu ao proprietário, prejudicado pela sombra dos ramos de uma árvore plantada no prédio vizinho, o direito de exigir o

\footnotetext{
118 Vide TEIXEIRA DE FREITAS, ibidem $82^{17}$.

${ }^{119}$ Vide COELHO DA ROCHA, o.c. 142.

${ }^{120}$ Vide COELHO DA ROCHA, o.c. 142.

${ }^{121}$ Vide COELHO DA ROCHA, o.c. 142.

${ }^{122}$ Vide Orlando GOMES, Direito de família $^{11}$ (Editora Forense / Rio de Janeiro, 1999) 175.

${ }^{123}$ Cf. D. $10,2,13$.

${ }^{124}$ Esta lei terá sido aprovada nos meados do século V a.C. Vide Sebastião CRUZ, o.c. 182.

${ }^{125}$ Vide SANTOS JUSTO, Direito privado romano III (Direitos reais), cit. 34.
} 
corte dos ramos até à altura de 15 pés e de os cortar se o dominus arboris recusasse. $\mathrm{O}$ vizinho podia também cortar e apoderar-se das árvores inclinadas sobre o seu prédio, se o dono as não cortasse ${ }^{126}$.

Nas suas Instituições, COELHO DA ROCHA ensina que o proprietário de um prédio "pode fazer as plantações que quiser". Todavia, "plantando junto aos confins do prédio vizinho, deve deixar o interstício de dois palmos, enquanto às árvores de pequeno tronco (...) e de nove, sendo a árvore de grosso tronco, excepto se outro for o costume do lugar". Quanto às raízes, entende que as pode cortar "dentro dos limites do seu prédio, assim como obrigar o vizinho a que corte os ramos que sobre ele propendem".

Depois, questionando se o vizinho pode pedir uma indemnização pelas perdas resultantes da sombra das árvores ou o seu corte quando estão situadas à distância legal, COELHO DA ROCHA refere que "em alguns lugares assim se pratica em favor da agricultura". Porém, entende que "não será fácil achar lei em que se funde esta prática" porque "se a agricultura merece ser favorecida, não o merece menos a cultura das árvores"127.

TEIXEIRA DE FREITAS segue a mesma orientação. No seu Esboço, escreve que "é proibido plantar as árvores de grande copa ou de longas raízes, se entre o lugar da plantação e a linha divisória do imóvel contíguo não mediar a distância de três metros ao menos" ${ }^{128}$, distância que, tratando-se de outras árvores e arbustos, é reduzida para metro e meio ${ }^{129}$. Se estas distâncias não forem guardadas, "o dono do imóvel contíguo poderá demandar para que as plantações sejam arrancadas" 130 . E "ainda que plantadas ou nascidas fora das mencionadas distâncias, se alguma árvore lançar ramos ou raízes para o imóvel contíguo, o dono deste poderá desbastar ou cortar a parte que lhe for nociva, contanto que não ultrapasse a linha perpendicular divisória"131.

Quanto aos frutos, os dois jurisconsultos afirmam que pertencem ao dono da árvore, salvo se esta se situar numa coisa possuída de boa fé, situação em que pertencem ao possuidor ${ }^{132}$.

A imposição de uma distância que afaste as árvores da linha divisória dos prédios é uma marca romana destinada a evitar a conflitualidade nas relações sempre frágeis da vizinhança. Os nossos jurisconsultos não a questionaram, embora, anos mais tarde, os dois legisladores se tenham afastado: o português

\footnotetext{
${ }^{126}$ Vide SANTOS JUSTO, ibidem 34.

${ }^{127}$ Vide COELHO DA ROCHA, o.c. II, 408-409.

${ }^{128} \mathrm{Cf}$. art. $4247,1^{\circ}$.

${ }^{129} \mathrm{Cf}$. art. $4247,2^{\circ}$.

${ }^{130} \mathrm{Cf}$. art. 4248 .

${ }^{131}$ Cf. art. 4249.

${ }^{132}$ Vide COELHO DA ROCHA, o.c. 311-312; e TEIXEIRA DE FREITAS, Esboço II, cit., 580.
} 
porque, não querendo ou não podendo afastar o minifúndio, difundido sobretudo no Norte de Portugal, permitiu que as árvores, salvo as gravemente lesivas da agricultura, das fontes ou de prédios urbanos, sejam plantadas até à linha divisória ${ }^{133}$; o brasileiro, porque não fixou, segundo cremos, espaço algum e, por isso, foi necessário determinar que "a árvore, cujo tronco estiver na linha divisória, presume-se pertencer em comum aos donos dos prédios confinantes"134; e que "as raízes e os ramos de árvore, que ultrapassarem a estrema do prédio, poderão ser cortados, até o plano vertical divisório, pelo proprietário do terreno invadido"135.

Todavia, se os dois legisladores permitem que as árvores sejam plantadas até à linha divisória, importa observar uma diferença que os separa. Referimo-nos à propriedade dos frutos caídos no prédio vizinho. Segundo o direito português, pertencem ao proprietário da árvore; por isso, é-lhe reconhecido o direito potestativo de invadir o terreno do vizinho, para os recolher, sem prejuízo de o dever indemnizar se causar danos ${ }^{136}$. Porém, o direito brasileiro atribui esses frutos ao "dono do solo onde caírem, se este for de propriedade particular" 137.

Neste aspecto, o direito português não se afastou do direito romano que a nossa tradição jurídica acolheu. A influência dos direitos alemão e italiano impôs-se no direito brasileiro, podendo questionar-se por que título o proprietário do prédio vizinho adquire a propriedade de frutos produzidos em árvores alheias ${ }^{138}$.

\section{Os Códigos Civis brasileiros}

\subsection{Preliminares}

Não se ignora o contributo importantíssimo de TEIXEIRA DE FREITAS na elaboração do primeiro Código Civil brasileiro. A Consolidação das Leis Civis, publicada em 1858 constitui trabalho preparatório e mereceu de Sílvio MEIRA as seguintes palavras: "é um monumento legislativo ante o qual se inclinam, com respeito, juristas de várias nações"139. Seguiu-se o Esboço do Código publicado alguns anos mais tarde, onde TEIXEIRA DE FREITAS se antecipou, com a parte geral, quarenta anos ao famoso Código Civil alemão, como observa René DAVID ${ }^{140}$.

33 Cf. art. $1366^{\circ}$. do Código Civil português.

${ }^{134}$ Cf. arts. 556 e 1282 dos Códigos Civis, respectivamente, de 1916 e de 2002.

${ }_{135}$ Cf. arts. 558 e 1283 dos Códigos Civis, respectivamente, de 1916 e de 2002.

${ }^{136}$ Cf. art. $1367^{\circ}$. do Código Civil.

137 Cf. arts. 557 e 1284 dos Códigos Civis, respectivamente, de 1916 e de 2002.

138 Vide SANTOS JUSTO ,Direitos reais (Coimbra Editora / Coimbra, 2007) 249.

139 Vide Sílvio MEIRA, o.c. 109.

140 Vide René DAVID apud Sílvio MEIRA, ibidem 455; e J. G. B. CÂMARA, Subsídios para a história do direito pátrio III (Rio de Janeiro, 1966) 162. 
Não surpreende, portanto, que o Código Civil brasileiro de 1916 seja uma obra notável que CORDEIRO ALVAREZ sintetizou eloquentemente, escrevendo: "C'est la plus haute expression du droit civil americain, et une des ouvres legislatives les plus remarquables du monde" 141 . E se à auctoritas de CORDEIRO ALVAREZ juntarmos a douta opinião de MOREIRA ALVES para quem, no Tratado de ENNECCERUS, KIPP e WOLFF, o Código Civil brasileiro é considerado "a mais independente das codificações latino-americanas" porque "se funda em ideias dos juristas brasileiros e recolhe o direito consuetudinário"142, ficaremos tranquilamente desobrigados de outras considerações e do risco duma apreciação provavelmente deficitária.

No entanto, importa esclarecer que há, no Código Civil brasileiro, influências francesas, alemãs e argentinas. Como simples exemplos das primeiras, destacamos os deveres conjugais ${ }^{143}$ e a fixação proporcional de alimentos de acordo com as necessidades do alimentando e os recursos da pessoa obrigada ${ }^{144}$; das segundas, a relevância do erro sobre as qualidades pessoais na anulação do casamento ${ }^{145}$ e a extensão do direito de propriedade só à altura ou profundidade que interessem ao proprietário $^{146}$; e das últimas, o âmbito da indemnização no caso de homicídio ${ }^{147}$.

Porém, não ofuscam as influências da tradição jurídica luso-brasileira que reflectem a preocupação da doutrina brasileira, na linha de TEIXEIRA DE FREITAS. Referimos tão-só alguns aspectos:

- o regime supletivo da comunhão geral de bens ${ }^{148}$;

- a compra e venda que, só por si, não transfere a propriedade ${ }^{149}$;

- a regra de que o comprador de coisa locada pode despedir o locatário se o contrário não tiver sido convencionado ${ }^{150}$.

No entanto, sempre que se julgou necessário, aquela tradição foi afastada. Constituem inovações, v.g.:

141 Vide E. CORDEIRO ALVAREZ, Amérique latine em Travaux de la semaine internatonale de droit (Paris, 1954) 744.

142 Vide José Carlos MOREIRAALVES, A contribuição do antigo direito português no código civil brasileiro em Estudos de direito civil brasileiro e português (I Jornadas Luso-Brasileiras de Direito Civil) (São Paulo, s/d) 38 .

${ }^{143}$ Cf. arts. $231^{\circ}$. e $203^{\circ}$. e $212^{\circ}$., respectivamente, do Código Civil brasileiro e do Code Civil francês.

${ }^{144}$ Cf. arts. $400^{\circ}$. e $208^{\circ}$., respectivamente, do Código Civil brasileiro e do Code Civil francês.

${ }^{145} \mathrm{Cf}$. art $^{\circ} .219^{\circ}$. I do Código Civil brasileiro.

146 Cf. art. $526^{\circ}$. do Código Civil brasileiro.

${ }^{147} \mathrm{Cf}$. arts. $1537^{\circ}$. e $1084^{\circ}$., respectivamente, do Código Civil brasileiro e do Código Civil argentino.

148 Cf. art. $258^{\circ}$.

${ }^{149}$ Cf. art. $1122^{\circ}$.

${ }^{150}$ Cf. art. $1197^{\circ}$. 
- a admissão da usucapião trintenária com base na posse de má fé ${ }^{151}$;

- o abandono da regra romana nemo pro parte testatus pro parte intestatus decedere potest $t^{152}$.

Filho do seu tempo, não surpreende que o Código Civil brasileiro tenha sido criticado por ser individualista, reflectindo a estrutura agrária da sociedade brasileira e uma economia dominada pelo binómio da exportação de matériasprimas e de géneros alimentares e da importação de artigos fabricados. Por isso, e embora não deixe de ser obra progressista em inúmeros passos como reconheceu Orlando GOMES ${ }^{153}$, o progresso social começou a reclamar um novo Código, tornando insuficientes as diversas alterações por obra de leis avulsas, sobretudo no domínio do estatuto familiar da mulher ${ }^{154}$.

Em 1969 foi nomeada uma Comissão para elaborar um projecto do novo Código Civil, elevado, em 1975, a Projecto de Lei nº .634 . Presidiu a uma ilustre plêiade de juristas o Prof. Miguel REALE cuja auctoritas é desnecessário invocar. Merecem eco as suas palavras, que pedimos vénia para transcrever: "Não tivemos a preocupação de mudar, mas a vaidade de conservação"; e "não elaboramos um Código, enfileirando sobre a mesa os códigos estrangeiros, para a escolha do melhor dispositivo. As estruturas verdadeiras são aquelas que brotam ab imis fundamentis. É grande a lição de Roma: o direito desenvolve-se à medida que a necessidade vai exigindo e os factos vão ditando" 155 .

E, na verdade, trata-se dum Projecto que concilia sabiamente o respeito pela tradição jurídica luso-brasileira com a necessidade de inovar. Por exigência do tempo, referimos apenas alguns aspectos:

- a recusa da unificação, num só Código, dos direitos civil e comercial;

- a consagração duma secção aos direitos de personalidade ${ }^{156}$;

- a admissão das responsabilidades subjectiva e objectiva, constituindo aquela a regra ${ }^{157}$;

- a estrutura familiar com base na igualdade dos cônjuges ${ }^{158}$;

- o regime supletivo da comunhão de adquiridos ${ }^{159}$;

151 Cf. art. $1574^{\circ}$.

${ }_{152}$ Vide supra, $\mathrm{n}^{\circ}$. 2.6.

153 Vide Orlando GOMES, Raízes históricas e sociológicas do código civil brasileiro (Baía, 1958), 40, 42., $46,48,56,57,66,71$ e 72.

${ }^{154}$ Cf. a Lei $\mathrm{n}^{\mathrm{o}} .4121$ de 27 de Agosto de 1962, que consignou o estatuto da mulher casada. Vide T. A. LOPEZ DE MAGALHÃES, O papel da mulher na sociedade na RFDSP 75 (1980) 127-128.

155 Vide Miguel REALE, Considerações gerais sobre o projecto de código civil (Projecto de lei $n^{\circ}$. 634, de 1975) na RFDSP 71 (1976) 57-58.

${ }_{156} \mathrm{Cf}$. arts. $70^{\circ}$. a $81^{\circ}$.

${ }_{157}$ Cf. $\operatorname{art}^{\circ} .483^{\circ} . n^{\circ} .2$.

${ }^{158}$ Cf. arts. $1671^{\circ}$. a $1677^{\circ}$.

${ }^{159}$ Cf. art. $1717^{\circ}$. 
- a não distinção entre filhos legítimos e ilegítimos na sucessão dos seus ascendentes ${ }^{160}$

- a vocação sucessória do cônjuge supérstite como herdeiro legítimo em posição privilegiada ${ }^{161}$;

Porém, a sociedade brasileira não deixou de evoluir com a celeridade que marca os nossos tempos. A aprovação do Projecto de 1975 tardava e ia-se tornando desactualizado. Em 17 de Maio de 1984, a Câmara dos Deputados aprovou a nova versão desse Projecto, mas o novo Código Civil não foi aprovado. A sua reestruturação impunha-se, sobretudo em virtude de recentes modificações legislativas, e foi confiada aos Profs. Miguel REALE e José Carlos MOREIRA ALVES, consagrado romanista e Ministro. Finalmente, em10 de Janeiro de 2002, foi aprovado o novo Código Civil brasileiro pela Lei $\mathrm{n}^{\circ} .10 .406$ e entrou em vigor em Janeiro de 2003.

Cumpre-nos, agora, apreciar alguns institutos que, estamos certos, mantêm actuais as palavras de Guilherme BRAGADACRUZ: "Portugal e Brasil continuam a ser, no direito, duas pátrias irmãs que se orgulham da sua ascendência comum"162.

\subsection{PARTe Geral}

A parte geral do novo Código contém um capítulo (o II) dedicado aos direitos de personalidade, com regras que tutelam os valores da subjectividade, a imagem e a intimidade e até o direito sobre o corpo para fins de transplante. Trata-se duma inovação de grande alcance, sobretudo nos nossos dias em que é enorme a tentação de violar a vida privada no que tem de mais elevado e nobre. O legislador brasileiro revela-se atento, mostrando-se, também aqui, uma aproximação ao direito civil português ${ }^{163}$.

Depois, destacamos o instituto da lesão enorme a que o novo Código consagra uma secção específica (a V) integrada no capítulo IV dos defeitos do negócio jurídico. Ignorada no Código de 1916 e mais tarde introduzida no Código de Defesa do Consumidor (Lei Federal nº 8.078 de 11 de Setembro de 1990) ${ }^{164}$, a lesão, a que os Glosadores de Bolonha chamaram laesio enormis ou ultra dimidium com base em duas constitutiones do direito romano ${ }^{165}$, começou

${ }^{160}$ Cf. arts. $2133^{\circ}$., $2139^{\circ}$., $2140^{\circ}$., $2157^{\circ}$. e $2159^{\circ}$.

${ }^{161}$ Cf. arts. $2157^{\circ}$. a $2161^{\circ}$.

162 Vide Guilherme BRAGA DA CRUZ, Formação histórica do moderno direito privado português e brasileiro em Scientia Iuridica (Braga, s/d) 37.

163 O Código Civil português consagra uma secção aos direitos de personalidade, onde contém normas sobre a tutela geral e tutela especial. Cf. $\operatorname{art}^{\circ} \mathrm{s} .70^{\circ}$. a $81^{\circ}$.

${ }_{164}$ Cf. art. $6^{\circ}$.

165 Cf. C. $4,44,2 ;-4,44,8$. 
por ser considerada um desequilíbrio de prestações sem que o animus das partes assumisse qualquer relevo, justificando a rescisão do contrato se fosse superior a metade do preço da coisa vendida. BÁRTOLO, caput scholae dos Comentadores e considerado um dos maiores, senão o maior jurisconsulto de todos os tempos ${ }^{166}$, estendeu-a a qualquer tipo de contrato, influenciando o direito canónico que considerou pecaminoso todo o proveito exagerado obtido por um dos contraentes à custa do outro.

Nos séculos XVI e XVII, o valor da lesão fixou-se em 1/3 e denominou-se enormissima laesio ou desequilíbrio superior a metade ${ }^{167}$. As nossas Ordenações Filipinas determinaram que "se fôr achado que o vendedor foi enganado além da metade do justo preço, póde desfazer a venda por bem do dito engano ainda que o engano não procedesse do comprador, mas sómente se causasse da simpleza do vendedor". Quanto ao comprador, "poderá isso mesmo desfazer a compra, se foi pela dita maneira enganado além da metade do justo preço" ${ }^{168}$. Se o vendedor "desfazer o contracto (...) ficará a escolha no comprador, ou tornar-se a cousa, e receber o preço, que por ella deu, ou refazer-lhe o justo preço (...) E querendo o comprador desfazer o contracto (...) ficará a escolha ao vendedor, ou tornandolhe o preço, que houve, e cobrar a cousa vendida, ou tornar-lhe a maioria que delle recebeu, além do que a cousa justamente valia ao tempo do contracto"169. $\mathrm{E}$ "todo o dito he, ha lugar não sómente nos contractos de compras e vendas mas ainda nos contractos dos arrendamentos, e foramentos, escaimbos, transacções, e quaesquer outras avanças, em que se dá, ou deixa huma cousa por outra"170. Mais adiante, as mesmas Ordenações falam, sem definir, de engano enormíssimo para efeitos da restituição da coisa e dos frutos produzidos após a venda ${ }^{171}$. Nos primeiros textos, consagra-se a laesio enormis e justifica-se com o erro em que a parte prejudicada pode incorrer seja por obra da contraparte, seja de si próprio; e no último, surge a laesio enormissima reconhecida por COELHO DA ROCHA ${ }^{172}$ e por TEIXEIRA DE FREITAS ${ }^{173}$ e que, segundo CORREIA TELLES, ocorre "quando alguém recebeo sómente a terça parte do justo valor da cousa174.

166 Vide Sebastião CRUZ, o.c. 98.

167 Vide Jorge Eustácio da Silva FRIAS, Da "laesio enormis". Algumas considerações no BFD LXXVII (2002) 765-767.

168 Cf. Ordenações Filipinas, IV,13pr.

$169 \mathrm{Cf}$. Ordenações Filipinas, IV,13.1.

${ }^{170}$ Cf. Ordenações Filipinas, IV,13.6.

${ }_{171} \mathrm{Cf}$. Ordenações Filipinas, IV,13,10.

172 Vide COELHO DA ROCHA, o.c. 509.

173 Vide TEIXEIRA DE FREITAS, Consolidação das leis civis, cit. art. 359., nota (2).

174 Vide J- H. CORREA TELLES, Digesto portuguez ou tatado dos direitos e obrigações civis accommodado às leis e costumes da Nação Portugueza para servir de subsídio ao novo código civil $\mathrm{I}^{3}$ (Imprensa da Universidade / Coimbra, 1845) 253. 
O Código Civil português de 1867 não consagrou a lesão como figura autónoma, preferindo considerá-la sob a perspectiva do erro "que annulle $o$ consentimento" 175 . Acolheu, portanto, a crítica que a considerava desnecessária, porque bem podia incluir-se entre o erro, dolo ou coacção, ou seja, entre os vícios da vontade. No entanto, o Código de 1966 afastou-se desta posição e considerou a lesão um negócio usurário com contornos objectivo e subjectivo ${ }^{176}$.

Quanto ao direito brasileiro, a laesio enormis e enormissima vigorou até 1916, por força das Ordenações Filipinas e da Lei de 20 de Outubro de 1823. Surge ainda na Consolidação das Leis Civis de TEIXEIRA DE FREITAS, mas, como sucedeu no Código Civil português de 1867, o Código Civil brasileiro de 1916 não a considerou figura autónoma. Em 1990, a Lei Federal nº 8078 introduziu-a no Código de Defesa do Consumidor ${ }^{177}$ e o actual Código Civil consagra a sua autonomia e dota-a de requisitos objectivo e subjectivo: a prestação "manifestamente desproporcional"; e a necessidade ou inexperiência do prejudicado ${ }^{178}$.

Podemos concluir, portanto, que os actuais Códigos Civis português e brasileiro consagram o mesmo instituto, embora com nomes diferentes: negócio usurário e lesão.

\subsection{PARTe ESPECial}

\subsubsection{DiREITO DAS OBRIGAÇÕES}

\subsubsection{COMPRA E VENDA}

Já referimos a sua natureza no direito romano e nas sucessivas Ordenações de Portugal; e assinalámos a sua evolução na doutrina portuguesa e no Código Civil de 1867.

A alteração do efeito obrigacional para real constituiu um dos temas da notável polémica que opôs TEIXEIRA DE FREITAS ao Autor daquele Código, António Luís de SEABRA.

Em causa estava a questão nuclear do método que, segundo o jurisconsulto brasileiro, só podia partir da distinção entre direitos pessoais e reais. Por isso, fiel à sua formação romanística e coimbrã que recebeu em Olinda, TEIXEIRA DE FREITAS sustentava que o contrato de compra e venda só podia criar direitos pessoais, jamais reais, como pretendia SEABRA por influência do seu jusracionalismo e do Code Civil francês. ${ }^{179}$.

175 Cf. $\operatorname{art}^{\mathrm{o}} \cdot 1582^{\circ}$.

${ }^{176} \mathrm{Cf} . \operatorname{art}^{\mathrm{o}} .282^{\circ}$.

177 Cf. art. $6^{\circ}$.

178 Cf. art. $157^{\circ}$.

179 Cf. arts. $715^{\circ}$. e $1583^{\circ}$., respectivamente, do Código de Seabra e do Code Civil francês. 
Talvez ambos tenham tido a razão pelo seu lado por se apoiarem em pensamentos jurídicos diferentes: SEABRA era jusracionalista e TEIXEIRA DE FREITAS, pandectista. Mas esta polémica permite compreender as diversas soluções que os Códigos Civis de Portugal e do Brasil consagraram. E justifica a afirmação de BRAGA DA CRUZ de que, em vários aspectos, o direito civil brasileiro é mais português do que o direito civil português, embora não deixemos de registar, no direito brasileiro, um pequeno desvio da tradição jurídica romanoportuguesa: para esta, os riscos da coisa vendida correm por conta do comprador, mesmo que ainda não tenha adquirido a sua propriedade; pelo contrário, para o Código Civil brasileiro há uma repartição do risco: "até ao momento da tradição, correm por conta do vendedor e os do preço por conta do comprador" 180 .

\subsubsection{LOCAÇ̃̃o DE COISA}

Também já referimos o contrato de locação de coisa, desde o direito romano até ao século XIX.

De novo por influência de TEIXEIRA DE FREITAS, o Código Civil brasileiro de 1916 acolheu substancialmente o regime das nossas Ordenações Filipinas, com destaque para o princípio emptio tollit locatum ${ }^{181}$. Porém, na linha do Código Civil português de 1867, afastou-se da tradição romana luso-brasileira quando determina que "salvo ajuste em contrário, nem a esterilidade, nem o malogro da colheita por caso fortuito autorizam o locatário a exigir o abate no aluguer" ${ }^{\prime 182}$. Ou seja, os Códigos Civis português de 1867 e brasileiro de 1916 confluíram no afastamento da solidariedade medieval que tinha penetrado em Portugal e no Brasil. Por isso se compreende a posição crítica de Orlando GOMES que, com a devida vénia, transcrevemos: "(A economia baseava-se) na exploração da terra e a renda dos fazendeiros só poderia ser obtida mediante a desumana exploração do trabalhador rural (...) O Código Civil é obra de homens da classe média que o elaboraram nesse estado de espírito: a afirmação por excelência do regime capitalista de produção" 183 .

Não surpreende, portanto, que o actual Código Civil conserve este princípio na locação de coisa nem que tenha mantido a irrelevância da esterilidade ou de circunstâncias imprevisíveis que diminuam a colheita ${ }^{184}$ : é uma herança do Código de 1916 que, nesta matéria, perdoar-me-ão a

\footnotetext{
${ }^{180} \mathrm{Cf}$. art. $492^{\circ}$.

${ }^{181}$ Cf. art. $1197^{\circ}$.

${ }^{182} \mathrm{Cf}$. art. $1214^{\circ}$.

${ }^{183}$ Vide Orlando GOMES, o.c. 40, 42, 46, 48, 53, 56, 57, 66, 71 e 72.

${ }^{184} \mathrm{Cf}$. art. $576^{\circ}$.
} 
insistência, não seguiu a doutrina de TEIXEIRA DE FREITAS, preferindo aproximar-se do Código Civil português de 1867.

Todavia, com a evolução da sociedade brasileira produziram-se algumas alterações no arrendamento de prédios urbanos e rústicos: em 30 de Novembro de 1964, a Lei $\mathrm{n}^{\circ} .4504$ (Estatuto da Terra) concedeu preferência ao arrendatário na alienação do imóvel ${ }^{185} \mathrm{e}$ determinou que a alienação "não interrompe a vigência dos contratos de arrendamento ou de parceria", recusando, assim, o princípio romano emptio tollit locatum ${ }^{186}$. E a Lei $\mathrm{n}^{\circ} .8245$ de 18 de Outubro de 1991 concedeu ao locatário o direito de preferência na venda, cessão ou promessa de cessão de direitos ou dação em pagamento do prédio locado, embora tenha consagrado o princípio emptio tollit locatum na locação por tempo indeterminado ${ }^{187}$.

\subsubsection{DiREITO DE EMPRESA}

O livro II da parte especial do actual Código Civil brasileiro constitui uma inovação particularmente importante que veio confirmar o que Sílvio MEIRA escreveu sobre TEIXEIRA DE FREITAS: “... homem superior ao tempo e ao espaço em que vivia (...) Como todos os génios, antecipou-se ao futuro"188; e prossegue: "A pouco e pouco vamo-nos convencendo (...) do plano de Freitas (...) Temos a impressão de que sua ideia original ainda vingará totalmente nas melhores legislações do mundo contemporâneo. É uma questão de tempo, apenas"189.

$\mathrm{Na}$ verdade, a ideia de unificação do direito privado ou, talvez melhor, da invasão do direito comercial no direito civil é uma das originalidades do pensamento de TEIXEIRA DE FREITAS, corolário da sua lição romanista de que "omne ius quo utimur, vel ad personas pertine, vel ad res, vel ad actiones ${ }^{190}$. Afastadas as actiones para o direito processual, ficam-nos as pessoas e as coisas, ou seja, os direitos pessoais e os direitos reais ${ }^{191}$. Em consequência, TEIXEIRA DE FREITAS critica a arbitrária separação das leis denominadas Direito Comercial ou Código Comercial, em cuja origem vê "um grande depósito de usos, costumes e doutrinas lentamente formados por inércia das legislações". E propõe-se reparar os erros do passado através da composição de dois Códigos: um, Geral; o outro, Civil. Aquele conterá as definições necessárias; este, as normas que disciplinam

\footnotetext{
185 Cf. art. $92^{\circ} . \S 3^{\circ}$.

186 Cf. art. $92^{\circ} . \S 5^{\circ}$.

${ }^{187} \mathrm{Cf}$. arts. $27^{\circ}$. e $28^{\circ}$. Se o arrendamento por tempo determinado, a regra emptio lollit locatum poderá ser afastada se a locação contiver cláusula de vigência e estiver averbada junto à matrícula do imóvel.

188 Vide Sílvio MEIRA, o.c. 350.

189 Vide Sílvio MEIRA, o.c. 409.

190 Cf. GAIUS 1,8.

191 Vide Sílvio MEIRA, o.c. 115 e 117.
} 
a vida. No Código Geral, as leis ensinam, destinam-se aos homens da ciência; no Civil, as leis mandam, dirigem-se ao povo. As matérias do Código Comercial serão integradas no Código Civil ${ }^{192}$.

Esta ideia da unificação do direito privado, que viria a ter reflexos no Código Federal suíço das obrigações e no Código Civil italiano de $1942^{193}$, foi recusada no Brasil, onde o Ministro José de Alencar a considerou "um dos frutos muito prematuros" 194 . No entanto, as ideias dos grandes Mestres não perecem: são sementes que, mais tarde ou mais cedo, acabam por germinar, mostrando a genialidade de quem se antecipou ao tempo. Outros jurisconsultos não as esqueceram, como Alfredo VALADÃO, Herculano Marcos INGL S DE SOUSA e, já nos nossos dias, Haroldo VALADÃO, Caio Mário da SILVA PEREIRA, Miguel REALE e Orlando GOMES que nos fala da "dicotomia incongruente do Direito Privado" e da consagração da ideia "preconizada, antes de todos, pelo mais genial de nossos civilistas, Teixeira de Freitas"195

Poder-se-á argumentar, como Orlando de CARVALHO, que esta invasão de preceitos comerciais no Código Civil o converte num "bloco de leis sem coesão e sem sistema" ${ }^{196}$. E, independentemente das diferentes opiniões, importa reconhecer que se trata duma questão muito sensível com avanços e recuos. Não se ignora, v.g., que o fracasso do projecto franco-italiano do direito das obrigações de 1927 retirou algum optimismo aos prosélitos da unificação jurídica, pois países como Portugal, México, Peru, Venezuela, Honduras, Costa Rica, Colômbia e França mantiveram a divisão clássica do direito privado nos Códigos Civil e Comercial ${ }^{197}$.

No entanto, volvida centúria e meia, o Brasil acaba de consagrar a ideia de TEIXEIRA DE FREITAS, cumprindo-se a "profecia” de Sílvio MEIRA.

\subsubsection{DiREITO DAS COISAS}

\subsubsection{Propriedade}

Sensíveis à sábia advertência de IAVOLENUS de que "omnis defnitio in iure civile periculosa est' ${ }^{\prime 198}$, os jurisconsultos romanos não definiram a propriedade.

No entanto, estudando, mais tarde, a casuística romana, os Glosadores medievais definiram-na como "o direito de usar, fruir e abusar", transmitindo

\footnotetext{
192 Vide Sílvio MEIRA, o.c. 353-354.

193 Vide Sílvio MEIRA, o.c. 406.

194 Vide Sílvio MEIRA, o.c. 357 E 360.

195 Vide Sílvio MEIRA, o.c. 406-409; e Caio Mário SILVA PEREIRA, Código das Obrigações na RJBA I-II (Buenos Aires, 1965) 182-190.

196 Vide Orlando de CARVALHO, Teixeira de Freitas e a unificação do direito privado no BFD LX (1984) 50 e 57.

197 Vide A. SANTOS JUSTO, O Código de Napoleão e o direito ibero-americano no BFD LXXI (1995) 88-89.

${ }^{198}$ Cf. D. 50,17,202.
} 
a ideia de que se tratava duma propriedade marcada por um individualismo exacerbado e pelo egoísmo sem limites, paradigma da propriedade burguesa contestada pela doutrina socialista dos nossos tempos ${ }^{199}$.

É, no entanto, uma ideia errada. Já BÁRTOLO, estudando as fontes romanas, definira a propriedade como "o direito de dispor completamente de coisas corpóreas, a não ser que a lei proíba"200. O genial jurisconsulto da Escola dos Comentadores teve em atenção os textos que estabelecem limitações determinadas por interesses públicos, por motivos religiosos e morais e por interesses privados, sobretudo no âmbito das relações de vizinhança. Aquela definição revela a verdadeira dimensão do dominium romano, caracterizado por uma profunda marca social. Aliás, as fontes romanas têm inspirado as sucessivas doutrinas dos actos de emulação, do uso normal, das influências directas e, mais próximo dos nossos tempos, do abuso do direito ${ }^{201}$, provando-se, assim, o acerto daquela definição que percorre a História do Direito Português e encontrou guarida nos modernos Códigos, mesmo de raiz individualista de que é paradigma o Code Civil francês ${ }^{202}$.

$\mathrm{Na}$ linha do direito português, os Códigos Civis portugueses de $1867^{203} \mathrm{e}$ de $1966^{204}$ consagram a propriedade como direito limitado pela lei; e o princípio da tipicidade ou numerus clausus que impede a constituição, com carácter real, de restrições ou figuras parcelares desse direito ${ }^{205}$.

O Código Civil brasileiro de 1916 consagra a terminologia que POTHIER recolheu nas fontes romanas de propriedade plena e limitada (minus plena) ${ }^{206}$. Não utiliza a noção de BÁRTOLO seguida nos Códigos Civis europeus, mas não deixa de limitar a propriedade dando especial ênfase aos direitos de vizinhança, onde encontramos algumas soluções já fixadas na Lei nas XII Tábuas ${ }^{207}$.

O actual Código Civil brasileiro abandonou a terminologia propriedade plena $\mathrm{e}$ limitada e restringe o seu exercício à "consonância com as suas finalidades económicas e sociais", preservando "a flora, a fauna, as belezas naturais, o equilíbrio ecológico e o património histórico e artístico" e evitando "a poluição do ar e das águas"208.

Consagra a teoria de emulação ${ }^{209}$ e dedica um capítulo (o V) aos direitos de vizinhança, mantendo as soluções do Código de 1916. Adimensão social da propriedade

\footnotetext{
${ }^{199}$ Vide A. SANTOS JUSTO, Direito privado romano III (direitos reais) em Studia Iuridica 26, reimpressão (Coimbra, 1997) 16 e 36-37.

${ }^{200}$ Vide SANTOS JUSTO, ibidem 16.

${ }^{201}$ Vide SANTOS JUSTO, ibidem 35-37.

${ }^{202} \mathrm{Cf}$. art. $544^{\circ}$.

${ }^{203}$ Cf. art. $2170^{\circ}$.

${ }^{204} \mathrm{Cf}$. art. $1305^{\circ}$.

${ }^{205} \mathrm{Cf}$. art. $1306^{\circ}$. Vide SANTOS JUSTO, Direitos reais (Coimbra Editora / Coimbra, 2007) 35-41.

${ }^{206} \mathrm{Cf}$. art. $525^{\circ}$. O Código Civil português de 1867 (art. $2168^{\circ}$.) fala de propriedade absoluta ou resolúvel, singular ou comum, perfeita ou imperfeita.

${ }^{207}$ Cf. arts. $554^{\circ}$., $555^{\circ}$., $558^{\circ}$., $563^{\circ}$. e $564^{\circ}$.

${ }^{208} \mathrm{Cf}$. art. $1228^{\circ} . \S 1^{\circ}$.

${ }^{209}$ Cf. art. $1228^{\circ}$. $2^{\mathrm{o}}$.
} 
mostra-se inequivocamente no novo Código e não deixa de ser curiosa a consideração de que os frutos de árvore alheia caídos no terreno vizinho pertence, ao proprietário deste, mantendo a solução do Código de 1916. Já referimos este aspecto.

\subsubsection{SUPERFÍCIE}

A superfície é, no direito romano, um direito real transmissível inter vivos e mortis causa de, perpetuamente ou durante largo tempo, gozar, plena e exclusivamente, de um edifício construído em solo alheio, mediante o pagamento de um cânone anual denominado pensio ou solarium.

Trata-se duma figura que o engenho romano criou para afastar as consequências anti-económicas do princípio de que, pertencendo ao dominus fundi tudo o que lhe for acrescentado ou incorporado (superficies solo cedit), o edifício construído não podia deixar também de lhe pertencer. Os inconvenientes eram muito graves: o solo romano era propriedade do populus Romanus, de algumas instituições públicas e de uns poucos cidadãos, ou seja, não havia espaço para a cidade se desenvolver. Por isso, sem eliminar o velho princípio da absorvência, o proprietário do solo adquiria a propriedade do edifício nele construído, mas este tornava-se objecto de outro direito (o direito de superfície), por isso considerado um ius in re aliena ${ }^{210}$.

O direito português das diversas Ordenações não consagrou o direito de superfície e tão-pouco o Código Civil de 1867 o incluiu nas chamadas propriedades imperfeitas ${ }^{211}$, embora tenha previsto a possibilidade de, num prédio, existirem árvores alheias que o dominus fundi poderá obrigar-se a conservar num período não superior a trinta anos ${ }^{212}$. Só em 1948 este direito foi introduzido, como direito real, no ordenamento jurídico português e com um campo de aplicação muito restrito: só podia ser constituído pelo Estado, autarquias locais e pessoas colectivas de utilidade pública administrativa em terrenos do seu domínio privado ${ }^{213}$. Por isso, pode afirmar-se que "só no Código Civil actual foi dada ao instituto completa carta de alforria", nas palavras de CARVALHO FERNANDES ${ }^{214}$.

O direito de superfície é aí alargado a plantações em terreno alheio ${ }^{215} \mathrm{e}$ prevê-se a possibilidade de construir sobre edifício alheio, embora se apliquem as regras de propriedade horizontal ${ }^{216}$.

\footnotetext{
${ }^{210}$ Vide SANTOS JUSTO, Direito privado romano III (direitos reais), cit. 210-212.

${ }^{211}$ Cf. art. $2189^{\circ}$.

${ }^{212}$ Cf. art. $2308^{\circ}$.

${ }^{213}$ Vide José de OLIVEIRA ASCENSÃO, Direito civil. Reais ${ }^{4}$ (Coimbra Editora / Coimbra, 1987) 458.

${ }^{214}$ Vide Luís A. CARVALHO FERNANDES, Lições de direitos reais ${ }^{3}$ (Quid Júris ? / Lisboa, 2001) 409.

${ }^{215}$ Cf. art. $1524^{\circ}$.

${ }^{216}$ Cf. art. $1526^{\circ}$.
} 
Embora temporalmente muito distante do direito romano, vislumbra-se no direito de superfície uma significativa influência romana na estrutura (gozo perpétuo ou temporário); nos modos de constituição e de extinção; na transmissibilidade; na não cessação por falta de pagamento das prestações anuais; etc. ${ }^{217}$. Ou seja, o direito romano não desapareceu depois da codificação do nosso direito civil: mantém-se para fornecer soluções que as novas necessidades exigem.

O direito brasileiro só consagrou o direito de superfície no Código Civil de 2002 e em termos muito próximos do Código Civil português. Destaca-se, no entanto, uma diferença importante: o afastamento da perpetuidade ${ }^{218}$.

\subsubsection{USUCAPIÃO TRINTENÁRIA}

Já falámos da usucapião trintenária e, no breve percurso que fizemos, ficámos no século XIX, antes da codificação do direito civil português. Diremos, agora, que o Código de Seabra avançou na linha aberta pela Lei da Boa Razão e presente em COELHO DA ROCHA: consagrou a prescrição trintenária sem justa causa e de má fé, como fizera o Código Civil de Napoleão. Ou seja o direito português regressou ao direito romano, séculos depois de o ter afastado. O actual Código Civil só inovou na redução do tempo de posse para vinte anos ${ }^{219}$.

Quanto ao direito brasileiro, a sua história é comum à do direito português até 1916, quando o Código Civil consagrou a usucapião de coisa imóvel independentemente de título e de boa fé, se a posse durar vinte anos ${ }^{220}$. Havendo justo título e boa fé, basta que a posse de imóvel dure dez ou quinze anos, respectivamente, entre presentes (moradores no mesmo município) ou ausentes ${ }^{221}$. O actual Código Civil reduziu o tempo de vinte para quinze $\operatorname{anos}^{222}$ e para dezanos se "houver estabelecido no imóvel a sua moradia habitual 223. Consagram-se também prazos menores em situações específicas ${ }^{224}$.

Observa-se, portanto, que a evolução percorreu a mesma linha do direito português e as diferenças apenas traduzem exigências específicas da sociedade brasileira. Há, no entanto, uma alteração terminológica que separa os dois Códigos Civis brasileiros: no primeiro, fala-se de o usucapião $o^{225}$; no segundo, e por determinação da Lei n ${ }^{0} .6 .969$ de 10 de Dezembro de 1981, de a usucapião $^{226}$.

\footnotetext{
${ }^{217}$ Vide SANTOS JUSTO, ibidem 212.

${ }^{218}$ Cf. art. $1369^{\circ}$.

${ }^{219}$ Cf. art. $1296^{\circ}$.

${ }^{220}$ Cf. art. $550^{\circ}$.

${ }^{221}$ Cf. art. $551^{\circ}$.

${ }^{222} \mathrm{Cf}$. art. $1238^{\circ}$.

${ }^{223}$ Cf. art. $1233^{\circ}$. $\S$ único.

${ }^{224}$ Cf. arts. $1239^{\circ}$. e $1240^{\circ}$.

225 Vide secção IV, cap. II, tít. II, livro II; e secção V, cap. III, tít. II, livro II.

226 Vide secção I; cap. II, tít. III, livro III; e secção I, cap. III, tít. III, livro III.
} 
Ou seja, prevaleceu a regra gramatical sobre a clareza jurídica: se a usucapião é filologicamente um vocábulo feminino, importa acentuar que o usus constitui o elemento determinante da juridicidade. Não é qualquer capio, mas uma capio pelo usus, que pertence ao género masculino. De todo o modo, ainda aqui (e, na nossa opinião, mal), o direito brasileiro não está afastado do direito português ${ }^{227}$.

\subsubsection{DiREITO DA FAMÍLIA}

\subsubsection{RELAÇÕES PATRIMONIAIS ENTRE CÔNJUGES}

Também já referimos a história do regime supletivo da comunhão geral de bens no direito português e esboçámos o seu destino nos direitos português a brasileiro.

Em Portugal, o Código de Seabra manteve-se fiel à longa tradição jurídica portuguesa; por isso, afastou-se do Code Civil francês que optou pela comunhão de adquiridos $^{228}$ e consagrou a comunhão geral de bens como regime supletivo ${ }^{229}$.

Quanto ao direito brasileiro a comunhão universal vigorou desde a descoberta do Brasil e manteve-se no Código Civil de 1916 como regime supletivo ${ }^{230}$. A posição de TEIXEIRA DE FREITAS não terá sido irrelevante. Todavia, porque fomentava o chamado golpe de baú ${ }^{231}$, o legislador consagrou o regime de comunhão parcial, reaproximando-se do direito português ${ }^{232}$ e recuperando a velha tradição jurídica visigótica.

\subsubsection{DoTE}

O dote é uma figura jurídica com particular importância no direito romano, que se manteve até há relativamente pouco tempo nos direitos de Portugal e do Brasil. Por isso, impõe-se uma referência.

Nos primeiros séculos da história do direito romano, durante os quais a família era considerada uma comunidade de pessoas e de bens sujeitas ao poder de um chefe (paterfamilias), os bens que a esposa levasse para o casamento tornavam-se propriedade do marido. Alguns desses bens constituíam a figura do dote, que se pode definir como um conjunto de bens que a mulher, o seu pater ou outra pessoa transferia para o marido para a compensar da perda dos direitos

\footnotetext{
${ }^{227}$ Cf. arts. $1288^{\circ}$. e ss.

${ }^{228}$ Cf. art. $1393^{\circ}$.

${ }^{229}$ Cf. arts. $1098^{\circ}$. e $1108^{\circ}$.

${ }^{230}$ Cf. art. $258^{\circ}$.

231 Vide João de Matos ANTUNES VARELA, Direito da família (Livraria Petrony / Lisboa, 1987$) 432$.

${ }^{232}$ Cf. art. $1640^{\circ}$. do Código Civil português.
} 
hereditários em consequência da ruptura do vínculo com a sua família paterna e também para contribuir para as despesas da vida matrimonial e assegurar, finalmente, o sustento da mulher viúva e dos seus filhos ${ }^{233}$.

Embora se tornassem propriedade do marido, dissolvido o matrimónio, a mulher, a quem mais tarde foi concedida uma hipoteca privilegiada sobre o património daquele, podia recuperar os bens dotais que, igualmente com o tempo, acabaram por se considerar património da mulher, que os confiava à administração do marido. A esta evolução não foi estranha a transformação do matrimónio cum manu (que sujeitava à mulher ao poder marital) em matrimónio sine manu (no qual a esposa conservava a sua independência ${ }^{234}$.

Indiferente a essa transformação, o dote conservou, no direito romano, uma importância altíssima, a ponto de se censurar gravemente a mulher que contraísse matrimónio sem dote. E mesmo mais tarde, quando o dote constituiu um sinal de diferenciação económico-social, que distinguia as famílias ricas das pobres, o dote não perdeu a sua importância social porque Justiniano fixou um valor máximo, mas não o extinguiu.

No direito medieval das invasões germânicas, observamos outro tipo de dote quanto à sua origem: quiçá reflectindo a velha compra e venda da mulher, o preço (pretium puellae) foi substituído pelo dote que o noivo dá à noiva. Esta figura, que caracteriza o casamento por arras, viria a ser praticada depois da fundação de Portugal e transformou-se num dos regimes patrimoniais do casamento, sem afastar a liberdade de os nubentes optarem por outros: a comunhão geral e a comunhão de adquiridos (ou de ganâncias) ${ }^{235}$.

Mais tarde, quando as Ordenações Manuelinas fixaram a comunhão geral de bens como regime regra, aquela liberdade manteve- $\mathrm{se}^{236} \mathrm{e}$, portanto, conservou-se a possibilidade de os nubentes optarem pelo dote. E assim chegámos aos Códigos Civis portugueses de 1867 e de 1966, embora o regime dotal tenha caído quase inteiramente em desuso ${ }^{237}$. O dote continua a ser um conjunto de bens da mulher, sujeito a um regime especial proteccionista (v.g., a irresponsabilidade por dívidas) que se justifica "pela ideia de garantir a mulher casada contra a má ou infeliz administração do marido" ${ }^{238}$. Pode ser constituído pela própria mulher, pelo marido, pelos avós ou por qualquer terceiro ${ }^{239}$, ou seja, há reflexos do dote romano e do dote germânico.

\footnotetext{
${ }^{233}$ Vide SANTOS JUSTO, Relações patrimoniais entre cônjuges: do direito romano aos direitos português e brasileiro, cit. 331.

${ }^{234}$ Vide SANTOS JUSTO, ibidem 332-335.

${ }^{235}$ Vide SANTOS JUSTO, ibidem 343-345.

${ }^{236} \mathrm{Cf}$. Ordenações Manuelinas, IV,7pr.

${ }^{237}$ Vide Francisco Manuel PEREIRA COELHO, Curso de direito de família I. Direito matrimonial, tomo $2^{\circ} .^{2}$ (Unitas / Coimbra, 1970) 351.

${ }^{238}$ Transcrevemos PEREIRA COELHO, ibidem 351.

${ }^{239}$ Cf. art. $1739^{\circ} . n^{\circ} .1$.
} 
Todavia, na consequência da Revolução de 25 de Abril de 1974, o dote foi revogado pelo Decreto-Lei $n^{\circ} .496 / 77$, de 25 de Setembro, por efeito do princípio da igualdade de direitos e deveres dos cônjuges ${ }^{240}$, que não tolera a superioridade do marido nem regimes especiais que pressupõem a inferioridade da mulher.

No Brasil, o dote está previsto na Consolidação das Leis Civis de TEIXEIRADE FREITAS como regime optativo, dispondo-se que "os bens dotaes são inalienáveis (e) não podem ser hypothecados pelo marido, ainda que a mulher consinta" "241. Ademais, se esses bens "se derem estimados ao marido, a mulher terá direito de credora privilegiada"242, "no regime dotal a fiança não obriga os bens, que pelo contracto pertencem à mulher. Esses bens ficarão sempre salvos" ${ }^{243}$. Por isso, não admira que o Código Civil de 1916 tenha consagrado o regime dotal como supletivo ${ }^{244}$.

No entanto, também não surpreende que a sua escassa utilização e a consagração de um novo status familiar da mulher tenham determinado o seu afastamento no actual Código Civil que percorreu uma via semelhante à que fora seguida em Portugal. Observa-se, no entanto, a preocupação da proteger a família com o chamado bem de família consagrado nos dois Códigos Civis ${ }^{245}$. Trata-se, como se sabe, dum bem ou conjunto de bens afectados às necessidades familiares, que gozam de alguns privilégios ${ }^{246}$.

\subsubsection{LEGITIMAÇÃO POR MATRIMÓNIO SUBSEQUENTE}

Já nos referimos a este modo de legitimar um filho nascido fora da relação matrimonial.

Importa agora dizer que o Código Civil português de 1867 consagra esta figura, admitindo que "o matrimonio legitima os filhos nascidos antes delle das pessoas que o contrahem", embora se foram "reconhecidos pelos pães e mães no assento do casamento ou o foram no do nascimento dos mesmos filhos, ou em testamento ou escriptura publica, quer anteriores quer posteriores ao matrimonio"247

$\mathrm{O}$ actual Código Civil deu um passo mais, dispondo que "o casamento, ainda que putativo, legitima sempre, de pleno direito, os filhos que os contraentes hajam tido um do outro antes da celebração dele"248. Ou seja, a filiação passou a operar automaticamente por efeito do matrimónio.

\footnotetext{
${ }^{240}$ Cf. art. $1671^{\circ}$. do Código Civil

241 Cf. art. $122^{\circ}$.

${ }^{242}$ Cf. art. $123^{\circ}$.

243 Cf. art. $133^{\circ}$.

244 Cf. art. $278^{\circ}$. e ss.

${ }^{245}$ Cf. arts. $70^{\circ}$. a $73^{\circ}$. e $1771^{\circ}$. a $1722^{\circ}$. , respectivamente, dos Códigos de 1916 e 2002.

246 V.g., são isentos de execução por dívidas posteriores, salvo as provenientes de tributos relativos ao prédio ou de despesas de condomínio. Cf. art. $1715^{\circ}$.

247 Cf. art. $119^{\circ}$.

248 Cf. art. $1873^{\circ}$.
} 
Actualmente, por efeito da legislação de 1977 que pôs em prática as determinações da Constituição Portuguesa de 1976, desapareceu a referência a filhos ilegítimos ${ }^{249}$. E, em consequência, relativamente à mãe, a filiação dos filhos resulta do facto do nascimento ${ }^{250}$; e a paternidade dos filhos nascidos fora do casamento estabelece-se pelo reconhecimento ${ }^{251}$ que pode efectuar-se por perfilhação ou decisão judicial em acção de investigação ${ }^{252}$. E um dos modos de fazer a perfilhação é a declaração prestada perante o funcionário do registo civil ${ }^{253}$. Desapareceu, portanto, a legitimação por subsequente matrimónio.

Olhando para o direito brasileiro, o Código Civil de 1916 determina que "criando a família legítima, o casamento legitima os filhos comuns, antes dele nascidos ou concebidos" 254 . Consagra, portanto, a velha modalidade romana da legitimação per subsequens matrimonium. Modalidade que mereceu a Orlando GOMES as seguintes palavras: "A legitimação por seguinte matrimónio, com ou sem reconhecimento, é forma consagrada em todas as legislações. No direito nacional não se admite outra, valendo independentemente de outro ato pelo qual reconheçam os cônjuges a prole anterior" ${ }^{\prime 255}$.

Porém, o actual Código Civil afastou aquele regime, determinando que "o filho havido fora do casamento pode ser reconhecido pelos pais, conjunta ou separadamente" 256 ; e o reconhecimento poderá ser feito no registro do nascimento ${ }^{257}$. Portanto, o novo direito brasileiro não se afasta do actual direito português.

\subsubsection{DiREITO DAS SUCESSÕES}

\subsubsection{VOCAÇÃO SUCESSÓRIA DO CÔNJUGE SUPÉRSTITE}

$\mathrm{Na}$ época arcaica do direito romano, dominada pelo matrimónio acompanhado de conventio in manum que punha a mulher (uxor) na condição de filha (loco filiae) do marido (ou do sogro, se paterfamilias), a mulher era, como filha, herdeira do marido, integrando o primeiro grupo dos heredes $s^{258}{ }^{258}$. Depois, a partir dos últimos

\footnotetext{
${ }^{249}$ Vide ANTUNES VARELA, Direito da família, cit. 158-162.

${ }^{250}$ Cf. art. $1796^{\circ} . n^{\circ} .1$.

${ }^{251} \mathrm{Cf}$. art. $1796^{\circ} . \mathrm{n}^{\circ} .2$.

${ }^{252} \mathrm{Cf}$. art. $1847^{\circ}$.

${ }^{253}$ Cf. art. 1854 al. a).

${ }^{254} \mathrm{Cf}$. art. $229^{\circ}$.

${ }^{255}$ Vide Orlando GOMES, Direito de família ${ }^{11}$ (Editora Forense / Rio de Janeiro, 1999) 334.

${ }^{256} \mathrm{Cf}$. art. $1607^{\circ}$.

${ }^{257} \mathrm{Cf}$. art. $1.609^{\circ}$. I.

${ }^{258}$ Vide Sebastião CRUZ, Direito romano (ius romanum) I. Introdução. Fontes ${ }^{4}$ (Ed. do Autor / Coimbra, 1984) $227-228$.
} 
séculos da República, foi-se impondo a prática do casamento livre (sem conventio in manum), no qual a mulher conserva a sua independência, mas deixa praticamente de ser herdeira do marido: tão-só o pretor lhe reservava um lugar no afastado $4^{\circ}$. grupo (vir et uxor) do ius praetorium ${ }^{259}$.

Para acautelar a mulher na sua eventual viuvez, o noivo doava-lhe alguns bens que, além de contribuíram para os encargos matrimoniais, proporcionavamlhe a necessária subsistência após a morte do marido. Trata-se, nas palavras de Pietro BONFANTE, de um "appannagio e un socorso alla dona vedova" 260 .

$\mathrm{Na}$ Idade Média, a independência patrimonial dos cônjuges não favoreceu a sua vocação sucessória na herança do outro e o direito português não foi indiferente: continuou a privilegiar o vínculo de parentesco. Nas Ordenações Filipinas, o cônjuge sobrevivo só aparece em quarto lugar, depois dos descendentes, ascendentes e colaterais ${ }^{261}$. No entanto, esta posição de inferioridade sucessória foi depois atenuada pelo instituto do apanágio que, contemplando inicialmente a viúva com rendimentos anuais provenientes da casa do marido defunto ${ }^{262}$, acabou por se estender ao marido.

É assim que o Código Civil de 1867 determina que "o cônjuge que, por morte do outro, se achar sem meios de subsistência, terá direito a ser alimentado pelos rendimentos dos bens deixados pelo fallecido"263; e estabelece ainda que "os alimentos durarão, em quanto o alimentado delles precisar, ou não passar a segundas nupcias" 264 . O apanágio continua a justificar-se porque, como nas precedentes Ordenações Filipinas, o cônjuge sobrevivo ocupa o quarto lugar na ordem da sucessão legítima do cônjuge falecido ${ }^{265}$. Onerando coisas imóveis ou móveis sujeitas a registo (herdadas pelos herdeiros que ocupam uma das ordens anteriores), este direito representa tecnicamente um ónus real ${ }^{266}$ e não directamente um instituto sucessório ${ }^{267}$.

O actual Código Civil português conserva-o ${ }^{268}$, apesar de o cônjuge ocupar o primeiro lugar ${ }^{269}$, situação que não deixa de causar alguma estranheza, embora se possa justificar quando o quinhão de herdeiro legitimário seja exíguo e, portanto, insuficiente ${ }^{270}$.

\footnotetext{
${ }^{259}$ Vide Sebastião CRUZ, ibidem 227.

${ }^{260}$ Vide Pietro BONFANTE, Corso di diritto romano I. Diritto di famiglia (Attilio Sampaolesi Editora / Roma, 1925) 381 e 383.

${ }^{261}$ Cf. Ordenações Filipinas IV,94pr.; -IV,96pr. Vide COELHO DA ROCHA, o.c. 197 e 205.

${ }^{262}$ Cf. $\S 7$ do Decreto de 17 de Agosto de 1761 e o Decreto de 17 de Julho de 1778. Vide COELHO DA ROCHA, o.c. 169-170.

${ }^{263} \mathrm{Cf}$. art. $1231^{\circ}$.

${ }^{264} \mathrm{Cf}$. art. $1232^{\circ}$.

${ }^{265}$ Cf. art. $1969^{\circ}$.

${ }^{266}$ Vide SANTOS JUSTO, Direitos reais, cit. 97.

${ }^{267}$ Vide OLIVEIRA ASCENSÃO, o.c. 327.

${ }^{268} \mathrm{Cf}$. art. $2018^{\circ}$.

${ }^{269} \mathrm{Cf}$. art. $2133^{\circ}$.

${ }^{270}$ Vide OLIVEIRA ASCENSÃO, o.c. 326.
} 
Quanto ao direito brasileiro, o apanágio manteve-se em vigor até $1916 . \mathrm{O}$ primeiro Código Civil não lhe dedicou uma disposição específica, mas não deixou de contemplar o cônjuge sobrevivo estabelecendo que "o direito à prestação de alimentos é recíproco entre pais e filhos"271. Esta norma justifica-se sobretudo porque o cônjuge sobrevivo ocupa o terceiro lugar na ordem da vocação hereditária legítima ${ }^{272}$.

O actual Código Civil mantém o direito recíproco à prestação de alimentos entre pais e filhos ${ }^{273}$ e determina ainda que este direito cessa "com o casamento, a união estável ou o concubinato"274. Como no direito português, também estas normas podem causar alguma surpresa com a elevação da vocação hereditária do cônjuge sobrevivo ao primeiro, segundo e terceiro lugares da ordem sucessória legítima ${ }^{275}$.

Também aqui, os direitos de Portugal e do Brasil caminham lado a lado.

\subsubsection{O PRINCÍPIO NEMO PRO PARTE TESTATUS PRO PARTE INTESTATUS DECEDERE POTEST}

Já observamos que este princípio do direito romano só foi abandonado no direito português na sequência da Revolução liberal, através da doutrina que interpretou, em sentido diferente, uma disposição das Ordenações Filipinas que, para salvar os legados, determinou que se deviam considerar tacitamente instituídos herdeiros os filhos do testador ${ }^{276}$.

É agora tempo de olharmos para os Códigos Civis portugueses e brasileiros.

Antes, porém, do Código português de 1867, já a Lei de 9 de Setembro de 1769 afastou, no seu preâmbulo, a regra de que ninguém pode falecer em parte com testamento e em parte sem testamento. Portugal (o Brasil ainda era Portugal) abria-se à modernidade: doravante, era possível deixar legados sem instituir herdeiro e instituir herdeiro apenas numa parte da herança, coexistindo, portanto, herdeiros legítimos e legatários ${ }^{277}$ e herdeiros testamentários e legítimos. Por isso, não surpreende que os Códigos de 1867 e de 1966 tenham mantido o novo princípio ${ }^{278}$.

O Brasil percorreu também esta via, acolhendo a mesma solução ${ }^{279}$.

\footnotetext{
${ }^{271}$ Cf. arts. $397^{\circ}$. e $399^{\circ}$.

${ }^{272} \mathrm{Cf}$. art. $1603^{\circ}$.

${ }^{273} \mathrm{Cf}$. art. $1696^{\circ}$.

${ }^{274} \mathrm{Cf}$. art. $1708^{\circ}$.

${ }^{275} \mathrm{Cf}$. art. $1829^{\circ}$.

${ }^{276} \mathrm{Cf}$. Ordenações Filipinas, IV,82pr.

277 Vide COELHO DA ROCHA, o.c. 478-479; e ALMEIDA COSTA, o.c. 411.

${ }^{278}$ Cf. arts. $1735^{\circ}$. e $2179^{\circ}$., respectivamente, do Código Civil de 1867 e do Código Civil de 1966.

${ }^{279} \mathrm{Cf}$. arts. $1626^{\circ}$. e $1857^{\circ}$., respectivamente, do Código Civil de 1916 e do Código Civil de 2002.
} 


\section{Conclusão}

O brevíssimo esboço que apresentamos permite afirmar, com segurança, que nos direitos de Portugal e do Brasil circula a mesma linfa jurídica que caracteriza a família jurídica luso-brasileira.

Unidos pela mesma História que nos identifica culturalmente, os nossos Países constituem uma Pátria sabiamente edificada e protegida pela ciência jurídica a que nos orgulhamos de pertencer.

Não deixamos de viver na mesma casa, seja em Portugal ou no Brasil. A cultura identifica-nos e a sensibilidade anima-nos; por isso, se nos afastamos, logo nos reaproximamos, porque a alma lusíada é um cimento indestrutível que nos une como um só Povo de Estados irmãos.

Somos assim, Portugueses e Brasileiros. 